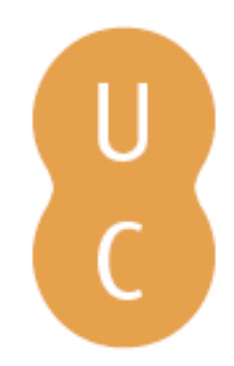

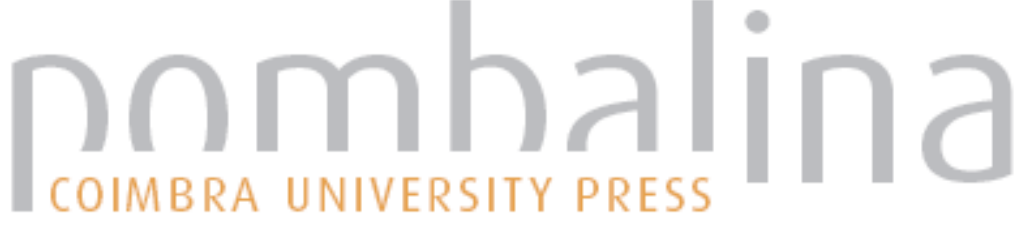

D. Maria Francisca Isabel de Sabóia (1646-1683), rainha de Portugal

Autor(es): $\quad$ Braga, Isabel M. R. Mendes Drumond

Publicado por: Imprensa da Universidade de Coimbra

URL

persistente: URI:http://hdl.handle.net/10316.2/32348

DOI: $\quad$ DOI:http://dx.doi.org/10.14195/978-989-26-0604-0_5

Accessed : $\quad$ 26-Apr-2023 11:41:54

A navegação consulta e descarregamento dos títulos inseridos nas Bibliotecas Digitais UC Digitalis, UC Pombalina e UC Impactum, pressupõem a aceitação plena e sem reservas dos Termos e Condições de Uso destas Bibliotecas Digitais, disponíveis em https://digitalis.uc.pt/pt-pt/termos.

Conforme exposto nos referidos Termos e Condições de Uso, o descarregamento de títulos de acesso restrito requer uma licença válida de autorização devendo o utilizador aceder ao(s) documento(s) a partir de um endereço de IP da instituição detentora da supramencionada licença.

Ao utilizador é apenas permitido o descarregamento para uso pessoal, pelo que o emprego do(s) título(s) descarregado(s) para outro fim, designadamente comercial, carece de autorização do respetivo autor ou editor da obra.

Na medida em que todas as obras da UC Digitalis se encontram protegidas pelo Código do Direito de Autor e Direitos Conexos e demais legislação aplicável, toda a cópia, parcial ou total, deste documento, nos casos em que é legalmente admitida, deverá conter ou fazer-se acompanhar por este aviso.

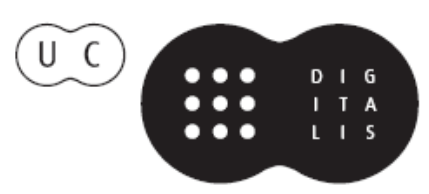




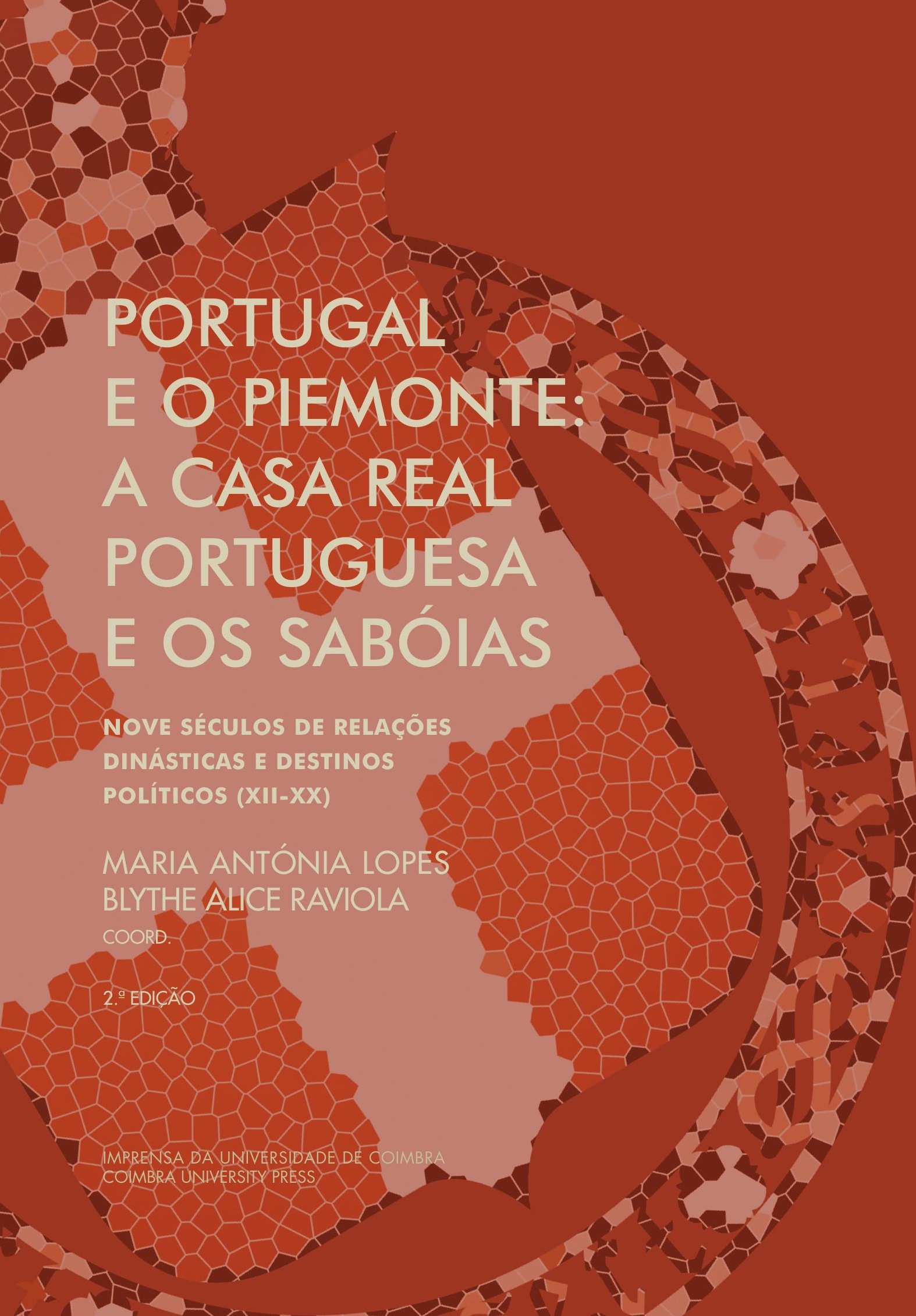


Isabel M. R. Mendes Drumond Braga

Universidade de Lisboa

\section{MARIA FRANCISCA ISABEL DE SABÓiA (1646-1683), RAINHA DE PORTUGAL}

Do casamento, realizado em 1643, entre Carlos Amadeu de Sabóia (1624-1652), duque de Nemours, de Aumale e de Genevois, e Isabel de Bourbon-Vendôme (1618-1664) nasceram cinco filhos: Maria Joana Baptista de Sabóia-Nemours (Paris, 1644 - Turim, 1724), Maria Francisca Isabel de Sabóia-Nemours (Paris, 1646 - Lisboa, 1683), que chegaram à idade adulta, e ainda José de Sabóia (1646-1647), Francisco de Sabóia (1650) e Carlos Amadeu de Sabóia (1651), que faleceram na infância ${ }^{1}$. Maria Francisca Isabel veio ao mundo a 26 de Junho de 1646, cinco horas antes de um irmão gémeo, José, que morreu com oito meses. Tanto quanto se sabe, a própria apresentava uma fraca compleição física ${ }^{2}$.

A morte precoce de Carlos Amadeu de Sabóia, em 1652, durante um duelo com o cunhado, Francisco de Bourbon-Vêndome, duque de Beaufort, reduziu a casa de Sabóia a quatro membros: Isabel de Bourbon-Vêndome, sua viúva; Maria Joana Baptista e Maria Francisca Isabel, suas filhas; e Henrique de Sabóia, arcebispo de Reims, seu irmão. As duas irmãs, órfãs de pai aos oito e aos seis anos respectivamente, foram educadas pelas religiosas de Fontevrault, estabelecimento para onde a mãe de ambas igualmente

\footnotetext{
* O texto que se apresenta tem como base investigação realizada e concretizada no texto $D$. Maria Francisca Isabel de Sabóia (1646-1683) que integra o volume D. Maria Francisca Isabel de Sabóia e D. Maria Sofia Isabel de Neuburg: Duas Rainhas em Tempo de Novos Equilíbrios Europeus, Lisboa, Círculo de Leitores, 2011. Todas as informações e interpretações aqui contidas podem ser vistas de forma mais desenvolvida na referida obra.

${ }^{1}$ BARBOSA, J., 1727, pp. 429-433.

2 ClARETTA, G., 1865, p. 71; DÓRIA, A. A., 1944, p.113.
} 
se retirou após a viuvez. Para Pierre Joseph d'Orléans, o primeiro biografo da rainha, em obra publicada em 1696, dedicada a D. Pedro II, a presença de Maria Francisca Isabel em Fontevrault assegurou-lhe uma educação real e cristã, que a habilitou em matérias como o saber viver, a polidez e o exercício da piedade 3 . Outras apetências também possuiu, pois chegou a compor poesia ${ }^{4}$. Algum tempo antes de falecer, Isabel de Bourbon-Vendôme abandonou a abadia com as duas filhas. Fixaram-se em Paris. Com a morte da mãe, em 1664, as duas irmãs foram entregues ao avô materno, César de Bourbon, duque de Vendôme, mas este morreu no ano seguinte. Viveram então recolhidas em conventos de Paris, primeiro no das Capuchinhas, depois no das Filhas de Santa Maria, onde a mãe fora sepultada 5 .

Ao longo do século XVI, o ducado de Sabóia distinguiu-se em termos geopolíticos, podendo constituir uma interessante reserva matrimonial para filhos segundos e para segundas núpcias. Na centúria seguinte, mormente após as guerras de religião, a França voltou a ser um parceiro importante no jogo internacional ${ }^{6}$, o que, concomitantemente, valorizou o ducado de Sabóia, cuja actuação estava dependente, por questões geográficas e familiares, de França. Não esqueçamos que a maior parte das negociações e das alianças políticas de então era feita tendo em conta os interesses familiares das casas reinantes ao ponto de se encararem os territórios como fontes de recursos e como meios para manter o poder e a honra das famílias e os interesses das dinastias ${ }^{7}$.

Ora, no mercado matrimonial de então, quer Maria Joana Baptista quer Maria Francisca Isabel tinham algum interesse. Já a mãe de ambas, Isabel de Bourbon-Vendôme, se começara a preocupar com o assunto, ponderando a opção de Sabóia, isto é, o casamento com Carlos Manuel II. Em 1659, chegaram a viajar para o ducado, tendo sido observadas, mas não terão suscitado grande interesse ao duque ${ }^{8}$. A 4 de Fevereiro de 1662, Maria

\footnotetext{
3 D'OrlÉANS, P. J., 1696, p. 5; ClareTTA, G., 1865, p. 77.

${ }^{4}$ BENEVIDES, F. F., tomo 2, 1879, pp. 113-114.

5 BARBOSA, J., 1748, pp. 6-7.

${ }^{6}$ BENNASSAR, B., 2006, pp. 40-41.

7 PARRALT, D., 2002, p. 156.

${ }^{8}$ Mémoires de Mademoiselle de Montpensier [...], vol. 5, pp. 271-273.
} 
Joana Baptista contraiu matrimónio com Carlos V, duque de Lorena (16431690). Pensou-se então em Maria Francisca Isabel para um outro membro da casa de Lorena, Carlos Henrique, conde de Vaudemont (1642-1723). Entretanto, o noivo da mais velha deixou França, entrou ao serviço do Imperador e o casamento não chegou a ser consumado. Já órfãs de mãe, das negociações dos seus casamentos ocupou-se César d'Estrées (1628-1714), bispo de Laon, membro da Academie Française (1658) e futuro cardeal (1672), primo em primeiro grau do duque de Vendôme. Os casamentos das duas irmãs implicaram contactos com Paris, Madrid, Turim e Lisboa?

As opções matrimoniais para Maria Francisca Isabel estiveram dependentes das pressões maternas e, após a morte da mãe, do interesse e da capacidade negocial de seu tio e tiveram que se harmonizar com a concorrência de outras mulheres, desde a sua irmã mais velha, Maria Joana Baptista, até às posições das diferentes cortes europeias, parcelas de peso neste jogo de interesses. Assim, se, como vimos, uma das primeiras hipóteses, não coroada de êxito, foi o duque de Sabóia, que acabou por se casar em segundas núpcias com Maria Joana Baptista, tal como desejava Isabel de Bourbon-Vêndome, outras possibilidades se seguiram, nomeadamente Carlos Henrique, conde de Vaudemont, e, finalmente, D. Afonso VI.

Para o rei de Portugal, Maria Francisca Isabel também não foi a primeira opção. Efectivamente, o marquês de Sande, Francisco de Melo e Torres (1620-1667), fora encarregado de negociar em França o casamento de D. Afonso VI com Mademoiselle de Montpensier, Ana Maria Luísa de Orleães, filha do duque de Orleães e prima co-irmã de Luís XIV, conhecida como a Grande Demoiselle ${ }^{10}$, já antes pensada para o príncipe D. Teodósio ${ }^{11}$. Mademoiselle de Montpensier, depois de protelar a resposta, acabou por não aceitar, mesmo tendo sido ameaçada de exílio, registando nas suas memórias alguns desses momentos ${ }^{12}$.

\footnotetext{
9 ORESKO, R., 2004, p. 17.

10 SANTARÉM, V., 1844 , pp. 515-523.

11 GONZALEZ, C., 2005.

12 Mémoires de Mademoiselle de Montpensier [...], vol. 5, pp. 232-238, passim. Mademoiselle de Montpensier apresentou uma visão fragmentária, caricatural e preconceituosa de Portugal e dos Portugueses tal como muitos outros Franceses seus contemporâneos. Cf. LESNE-JAFFRO, E., 2005.
} 
As negociações matrimoniais tiveram início com o envio a Paris do marquês de Sande. Depois de discutidas várias hipóteses durante o ano de 1663, foi, finalmente, escolhida Maria Francisca Isabel. A 29 de Outubro de 1664, o avô da noiva, o duque de Vendôme, enviou ao já referido bispo de Laon, seu primo, um poder para propor ao marquês de Sande o casamento ${ }^{13}$. A 10 de Abril de 1665, foram acordados os artigos e condições do consórcio entre o desembargador Pedro de Almeida do Amaral, o duque d'Estrées, Francisco Anibal I, e ainda o bispo de Laon ${ }^{14}$. O tratado de casamento foi assinado em Paris, a 24 de Fevereiro de 1666, pelo marquês de Sande e pelos já referidos duque d'Estrées e bispo de Laon ${ }^{15}$.

O articulado do tratado estipulava que o enlace fosse celebrado, por procuração, em Inglaterra - o que não foi possível devido a um surto de peste - e que a partir de então o embaixador de Portugal reconhecesse D. Maria Francisca Isabel como rainha de Portugal. O dote, mais elevado do que era costume, para evidenciar a grande consideração e a diferença das Casas de Nemurs e Vêndome face à Casa Real portuguesa, no valor de seiscentos mil escudos de moeda francesa, isto é, um milhão e oitocentas mil libras tornesas, ou quatrocentos mil escudos, representava uma garantia para a noiva, se houvesse dissolução do matrimónio. Como sempre, seria recuperável em caso de viuvez e não só dependeu da tradição, de exemplos passados, mas e, sobretudo, das relações de força entre as duas Casas envolvidas ${ }^{16}$, uma real e outra ducal. O que a noiva recebia deveria compensar o que renunciava ao abandonar o país dos seus antepassados 17 .

Tal como acontecera com as anteriores rainhas de Portugal, D. Maria Francisca Isabel receberia Casa e Estado, ou seja, um património comum com identidade jurídica, constituído pelo domínio senhorial de Aldeia Galega, Aldeia Gavinha, Alenquer, Alvor, Caldas, Chamusca, Faro, Mação, Reguengo de Viseu, Salir do Porto, Silves, Sintra e Ulme, após a morte

\footnotetext{
13 SANTARÉM, V., 1844, p. 551.

14 SANTARÉM, V., 1844, p. 557.

15 SANTARÉM, V., 1844, pp. 570-580; SOUSA, A. C., 1952, pp. 12-20.

16 BÉLY, L., 1999, p. 206.

17 BÉLY, L., 1999, p. 205.
} 
da sogra, D. Luísa de Gusmão ${ }^{18}$. Entretanto seria compensada monetariamente com trinta mil cruzados por ano. A casa da rainha seria estabelecida um mês após a chegada a Portugal "com a mesma grandeza e magnificência que as das outras rainhas que a precederam, e que é conveniente à sua qualidade e dignidade"19. A partir do momento em que D. Maria Francisca Isabel entrasse em Lisboa, passaria a usufruir de todos os direitos e privilégios que as anteriores consortes régias haviam beneficiado. No caso de ficar viúva, com ou sem filhos, não perderia nenhuma das prerrogativas referidas, poderia deixar o reino e, não tendo descendentes, teria direito à totalidade do dote e dos seus pertences, no caso de ter filhos, só teria direito a um terço do dote e aos referidos pertences. A D. Afonso VI cumpria dar, de arras, à rainha quarenta mil escudos em jóias.

O matrimónio por procuração, levado a efeito em La Rochelle, a 27 de Junho de 1666, marcou a separação de D. Maria Francisca Isabel com o reino de origem enquanto o enlace presencial selou a integração da rainha na sua nova família ${ }^{20}$. O noivado e o casamento foram, como sempre, realizados no reino da noiva antes da partida, por procuração, o que, desde logo, implicou uma dispensa papal pois, após Trento, todos os matrimónios pressupunham a expressão pública do consentimento mútuo ${ }^{21}$.

O itinerário de D. Maria Francisca Isabel compreendeu duas partes. A primeira, entre Paris e La Rochelle, via terrestre, passando por Estampes, um feudo Vendôme; Poitiers e La Rochelle ${ }^{22}$. A segunda de La Rochelle a Lisboa, via marítima, foi ameaçada por um fracassado projecto castelhano de arrebatar a rainha quando se preparasse para entrar em Lisboa 23 , além de ter conhecido calmarias e tempestades. A 30 de Junho, a comitiva embarcou em La Rochelle. A 3 de Julho, com ventos favoráveis, pôde zarpar. A 30, avistou as Berlengas e chegou a Cascais. A rainha foi visitada, a

\footnotetext{
18 Estas terras constituíam o domínio senhorial da casa da rainha, quando a mesma foi instituída em 1643. Cf. LOURENÇO, M. P. M., 1995, p. 998. Como D. Maria Francisca Isabel herdará da sogra essa posse, não se discriminaram no contrato de casamento todas as terras.

19 SOUSA, 1952, p. 15.

20 LEFERME-FALGUIÈRES, F., 2007, p. 105.

${ }^{21}$ LEFERME-FALGUIÈRES, F., 2007, p. 108.

22 CLARETTA, G., 1865, p. 90.

23 SANTARÉM, V., 1844, pp. CCIII-CCVI.
} 
bordo, por D. Luís de Vasconcelos e Sousa, conde de Castelo Melhor, e por D. Mariana de Lencastre, mãe do anterior, designada como camareira-mor de D. Maria Francisca Isabel. De Cascais, a comitiva seguiu até Belém, onde ancorou no dia 2 de Agosto, sendo saudada com artilharia ao longo do percurso. Finalmente, foi esperada pela nobreza, ricamente vestida e com excelentes montadas, e por muito povo, de tal modo que se comentou algo como: "Lisboa saiu de si própria para ir render as primeiras homenagens à princesa" 24 . Em Alcântara, na capela do Convento das Flamengas, o bispo de Targa deu as bênçãos aos esposos, mas D. Afonso VI acabou por deixar a mulher sozinha, quer no jantar quer, inclusivamente, durante a noite, segundo fontes afectas a D. Pedro ${ }^{25}$.

Antes da chegada da rainha, a cidade de Lisboa movimentou-se no sentido de fazer os preparativos necessários para a receber. As festas duraram de Agosto a Outubro, tendo decorrido em duas fases, uma vez que a rainha esteve doente em Setembro. Entre as manifestações de regozijo contaram-se diversas construções de arte efémera - arcos, apetrechos de fogo-de-artifício, embarcações - sendo de salientar que a arquitectura foi da responsabilidade de João Nunes Tinoco. Não era uma novidade, pois já no século XVI se recorria à arte efémera para festejar entradas de monarcas, casamentos régios e cerimónias religiosas ${ }^{26}$, nem tão pouco uma especificidade portuguesa, pois tais manifestações eram comuns pela Europa 27 .

Na ocasião do casamento de D. Afonso VI e de D. Maria Francisca Isabel foram feitas aguarelas com algumas imagens exibidas nos arcos triunfais que ornavam a cidade, para festejar a entrada do casal. A simbologia das pinturas e das inscrições foi objecto de estudo por parte de Ângela Barreto Xavier e Pedro Cardim, autores que salientaram, de entre outros aspectos, que a rainha foi louvada, tendo sido evidenciadas características e desejos inerentes à felicidade do casal, tais como a pureza, a castidade, o amor

\footnotetext{
24 Gazette, n. ${ }^{\circ} 126$, Paris, 22 de Outubro de 1666.

25 A reconstituição deste episódio não é pacífica, pois as fontes - algumas bastante comprometidas - têm informações pouco favoráveis a D. Afonso VI.

26 Arte Efémera em Portugal [...].

27 BOUZA AlVAREZ, F., 1996; ZANGLER, A. E., 2006.
} 
virtuoso, a fecundidade, a função protectora e a beleza, aproximando-se a imagem da consorte da figura arquétipa da Virgem Maria ${ }^{28}$.

Quando os monarcas entraram em Lisboa, a 29 de Agosto de 1666, Cristóvão Soares de Abreu proferiu uma oração encomiástica ${ }^{29}$. A cerimónia deu igualmente azo a várias composições poéticas no âmbito das Academias, nomeadamente na dos Generosos ${ }^{30}$ e na dos Singulares ${ }^{31}$. Porém, segundo o embaixador de França, na entrada do casal régio, a 29, "apenas a Rainha se salientava" 32 , ao mesmo tempo que fez saber que o povo tinha testemunhado uma grande alegria em ver a consorte de D. Afonso VI.

Quando a nova rainha chegou a Lisboa, a família real portuguesa não era propriamente grande. A sua sogra, D. Luísa de Gusmão, viúva de D. João IV, havia falecido meses antes, a 17 de Fevereiro de 1666. Uma das suas cunhadas, D. Catarina, estava casada com Carlos II de Inglaterra, desde 1662. Restavam D. Afonso VI e seu irmão D. Pedro, além de uma filha ilegítima de D. João IV, D. Maria, que se criara em casa do secretário António Cavide, seu tutor e curador. Em 1649, esta senhora entrou para o convento de Santa Teresa de Carnide. Embora não tenha professado, viveu em hábito de religiosa. D. Maria Francisca Isabel chegou a visitá-la e a orar e merendar no convento com ela ${ }^{33}$. Havia ainda soror Maria do Céu, filha do duque de Medina Sidónia e prima, pelo lado materno, de D. Afonso VI, freira professa no Convento de Nossa Senhora da Quietação.

As primeiras notícias acerca do relacionamento entre D. Afonso VI e D. Maria Francisca Isabel foram auspiciosas. Segundo Saint-Romain, embaixador de França em Portugal, o monarca passava muito tempo no quarto da mulher e quase não podia estar uma hora sem a ver ${ }^{34}$. Por outro lado, nas suas

28 XAVIER, A. B., CARDiM, P.; 1996, pp. 50-62, XAVIER, A. B., CARDIM, P., 2006, pp. 165-185.

29 ABREU, C. S., 1666, pp. 4-5.

30 Certamen Epithalamico [...], 1666.

31 Certamen Accademico Epitalamico [...], 1667. Sobre um dos autores das composições, António Serrão de Castro, cf. RIBEIRO, B. A. F., 2007, pp. 44-48. Muitas outras peças poéticas foram produzidas, cf. Poetica Discripcion [...], 1667 e PAIVA, 1667. Sobre as academias e a celebração do casamento, cf. XAVIER, A. B., CARDIM, P., 2006, p. 167.

32 Paris, AMAE-Q'O, Correspondance Politique. Portugal, n. ${ }^{\circ}$, fol. $245 \mathrm{v}$.

33 CAVAlHeIro, A. R., 1944, p. 35, passim.

${ }^{34}$ Paris, AMAE-Q'O, Correspondance Politique. Portugal, n. ${ }^{\circ}$ 5, fol. 228. 
memórias, Mademoisselle de Montpensier registou, com algum eventual despeito, que D. Maria Francisca Isabel escrevera uma carta a Madame de Béthune, que esta lera à rainha de França, na sua presença: "consumado o casamento, a Rainha escreveu a todas as suas amigas dando conta do quanto estava satisfeita, afirmando ter casado com o mais honesto homem do mundo e que apenas lhe faltava um filho, que esperava vir a ter em breve, para a sua felicidade ser completa"35. Note-se que estas informações, imediatamente a seguir ao casamento, contrastam com as que mais tarde vieram a lume, numa conjuntura que permitia justificar a anulação do enlace. Já nas memórias de d'Ablancourt, publicadas em 1701, logo, eventualmente tendeciosas, pode ler-se que o relacionamento do casal não era consentâneo com a idade que tinham e, consequentemetne, o relacionamento não se passava "de forma muito agradável"36.

Na corte de Lisboa, os problemas não se fizeram esperar. Parece claro que D. Afonso VI não era o homem mais dotado para ser rei, porém, a conjuntura e os que o rodeavam também contribuíram para a acentuada e rápida degradação do poder que ostentava na qualidade de monarca. Sendo o segundo filho, consequentemente não preparado para herdar a Coroa, a questão só se colocou em 1653, quando o primogénito de D. João IV e de D. Luísa de Gusmão, o príncipe D. Teodósio, faleceu. Com dificuldades diversas, problemas de saúde que mereciam preocupação e com uma educação pouco cuidada, o monarca ficou famoso pelas desordens que provocava integrado em bandos 37 ou com o seu companheiro de distúrbios favorito, o mercador António de Conti ${ }^{38}$. Se são pouco credíveis, ou pelo menos sujeitas a interrogações, afirmações contidas em fontes tendenciosas $^{39}$, também é certo que, na corte, antes da chegada da rainha, ia ganhando cada vez mais forma e volume uma facção que pretendia a queda do conde de Castelo Melhor. Era composta pelos que se opunham ao seu poder excessivo, nomeadamente, o duque de Cadaval, o marquês de

\footnotetext{
35 Mémoires de Mademoiselle de Montpensier [...], vol. 5, p. 311.

36 Mémoires de Monsieur d'Ablancourt [...], p. 294.

37 CURTO, D. R., 2007, p. 193

38 GUIRAUD, M., 2005.

39 Lisboa, B.N.P., Cod. 1505, fol. 22; SOUTHWEL, 1749, p. 31.
} 
Marialva, os condes de Sarzedas, Vila Flor, São João e da Torre, D. Rodrigo de Meneses (irmão do marquês de Marialva), Luís de Mendonça Furtado, D. João da Silva e D. Luís de Meneses (irmão do conde da Ericeira). Por volta de Junho ou Julho de 1666, começou a perceber-se que D. Pedro funcionava claramente como cabeça de partido. Neste último mês, Saint Romain aludia já à "cabala do Príncipe de Portugal" 40 .

Tudo se complicou quando D. Maria Francisca Isabel entrou em choque com o valido. Se, inicialmente, a rainha se dava bem com D. Luís de Vasconcelos e Sousa, segundo o depoimento do marquês de Saint-Romain ${ }^{41}$, rapidamente a situação se degradou quando a primeira começou a querer participar nas reuniões do Conselho de Estado, tal como fizera sua sogra D. Luísa de Gusmão, durante o reinado de D. João IV. A oposição do escrivão da puridade fez-se, então, sentir. Aparentemente, o conde quis uma rainha francesa mas não queria que ela se imiscuísse na governação ${ }^{42}$.

A conspiração, inspirada pelo desejo que Luís XIV nutria de afastar Castelo Melhor, foi o passo seguinte. A rainha contou com a colaboração dos Franceses que a assessoravam, nomeadamente o seu confessor, o padre Francisco de Villes, e o seu secretário, Luís Verjus, futuro conde de Crécy, sem esquecer o embaixador de França, o marquês de Saint-Romain, que, a partir de certo momento, se considerou ultrapasado pelos acontecimentos. Luís XIV pretendia o afastamento do escrivão da puridade para protelar a assinatura da paz entre Portugal e a monarquia de Carlos II, uma vez que a guerra da Restauração enfraquecia o reino de Castela e facilitava as pretensões francesas face aos Países Baixos espanhóis e ao Franco-Condado, o que, em 1667, desencadearia a chamada "Guerra da Devolução". Pelo contrário, a Inglaterra tinha interesse numa Península Ibérica pacificada, permitindo a Carlos II reagir ao ataque francês. Desde o início de 1666, o conde de Castelo Melhor, com o apoio inglês, foi negociando a desejada paz, estando-se prestes a alcançá-la. Assim se compreende que, para a França, o afastamento do titular fosse importante. Contudo, quando, em

\footnotetext{
40 BRAGA, P. D., 2006, p. 65.

41 PRESTAGE, E., 1933, p. 115.

42 MATOS, G. M., 1944, p. 352
} 
Março de 1667, os dois reinos assinaram uma liga ofensiva e defensiva, à França deixou de interessar a queda de Castelo Melhor ${ }^{43}$, o mesmo não se podendo afirmar em relação a D. Maria Francisca Isabel.

No reino, a situação política foi-se detriorando. Paralelamente ao afastamento do valido, delinearam-se as facções de D. Pedro e de D. Maria Francisca Isabel, apoiada pelo grupo francês. O consenso e a fusão entre ambas parecem ter sido rapidamente obtidos. Porém, como se iria proceder em termos de governação? A quem pertencia o governo? À rainha, enquanto regente? Ao infante, nessa mesma qualidade? Parecendo certo que a deposição de D. Afonso VI era uma questão de tempo, se D. Maria Francisca Isabel se mantivesse ao lado do monarca, ou o acompanharia durante o exílio ou teria que recolher-se a um convento. Por outro lado, se estivesse do lado da oposição ao marido, as opções seriam outras: não só teria legitimidade de requer a regência, como teria o apoio francês. Não podendo assegurar a regência, restava-lhe desposar o infante D. Pedro. Se bem que, seguramente, não tivesse interesse em passar de rainha a princesa, nessa conjuntura ser a mulher do regente era a melhor opção.

São particularmente interessantes as palavras de Ana de Oliveira Antunes, quando considerou que a rainha arriscou bastante ao conceder apoio a $\mathrm{D}$. Pedro: "Foi D. Maria que passou de rainha a princesa. Foi quem mais arriscou, desligou-se parcialmente da França, confiou no infante e no duque [de Cadaval], perdeu a Coroa, perdeu a oportunidade de ser nomeada regente" ${ }^{44}$. Contudo, também teremos de ponderar que para o reino seria mais fácil aceitar D. Pedro, irmão do monarca deposto, na condição de regente, do que uma mulher estrangeira récem chegada a Portugal e com uma atitude conflituosa, ou pelo menos não totalmente pacífica, com os ministros de seu marido. Um golpe de estado encabeçado pela rainha decerto levaria a uma sublevação e, na melhor das hipóteses, ao seu encerramento numa instituição religiosa. Assim, entre voltar para França em situação pouco abonatória ou passar a princesa a segunda opção terá sido a mais vantajosa.

\footnotetext{
43 PRESTAGE, E., 1933, p. 120; BRAGA, P. D., 2006, p. 67.

${ }^{44}$ ANTUNeS, A. M. P. O., vol. 1, p. 62.
} 
No final de Outubro de 1667, Sir Robert Southwell, embaixador inglês, já referia que D. Maria Francisca Isabel ainda era virgem e que poderia vir a casar com o infante D. Pedro ${ }^{45}$. A 9 de Novembro, o cônsul Maynard informou Lord Arlington de que a aliança luso-francesa era impopular e que os Portugueses desejavam a paz com Castela ${ }^{46}$. A 15, Sir Robert Southwell fez saber que todos acreditavam que D. Pedro e a rainha colaboravam e que em breve se casariam ${ }^{47}$. De facto, a 21 de Novembro de 1667, D. Maria Francisca Isabel, combinada com o infante D. Pedro ${ }^{48}$, abandonou o palácio, refugiando-se no convento da Esperança ${ }^{49}$, de onde escreveu a D. Afonso VI, no dia seguinte, solicitando autorização para partir para França e pedindo a restituição do dote ${ }^{50}$.

A 22 de Novembro, numa reunião no palácio da Corte Real, ficou decidido que D. Pedro e os seus partidários deveriam insistir junto de D. Afonso VI para este lhe entregar a governação. O monarca opôs-se e foi enclausurado. Estava a terminar a revolução palaciana iniciada com a deposição do secretário de Estado e que acabaria com a prisão de D. Afonso VI. Dois dias depois, D. Pedro explicou a situação, protestou lealdade ao soberano e informou que iria convocar Cortes, as quais abriram a 27 de Janeiro de 1668. Nesse mesmo dia, deu-se o juramento de D. Pedro como herdeiro do trono e discutiu-se o título que deveria tomar: Rei ou regente? A segunda opção salvaguardou a não abertura de um precedente que consistia nas Cortes considerarem que podiam depor um rei cuja actuação fosse considerada prejudicial ${ }^{51}$. Estes rápidos acontecimentos foram vistos em França com surpresa e apreensão. O embaixador de Luís XIV, o marquês de Saint-Romain, sentiu-se ultrapassado pela rainha e solicitou ao regente garantias de que não quebraria a liga assinada em Março de 1667. Entretanto,

45 Descritpive List of the State Papers [...], vol. 1, p. 78.

46 Descritpive List of the State Papers [...], vol. 1, p. 78.

47 Descritpive List of the State Papers [...], vol. 1, p. 80.

48 ANTUNES, A. M. P. O., vol. 1, pp. 51-54.

49 DÓRIA, A. A., 1944, p. 224.

50 Évora, BPE, Cod. CIII/2-25, fol. 14; BENEVIDES, F. F., tomo 2, 1879, p. 107; PAIXÃO, A., vol. 1, 1938, p. 44.

${ }^{51}$ Luís XIV ia ficando a par de todas estas questões, cf. Paris, AMAE-Q'O, Correspondance Politique. Portugal, n. ${ }^{\circ}$ 7, fol. 166. 
o monarca francês, a pretexto de ajudar Portugal, enviou 12 naus para o Tejo. A mensagem não era dada a interpretações dúbias.

Em cerca de ano e meio, a passagem da rainha pela corte de Lisboa deixava marcas consideráveis. Uma carta particular de António de Miranda Henriques, comendador de Panóias, dirigida a seu filho Bernardo de Miranda Henriques, governador de Pernambuco, datada de 17 de Dezembro de 1667, referiu o receio que vivia pois era igualmente pai de Henrique Henriques de Miranda, próximo do conde de Castelo Melhor, e sintetizou os acontecimentos: "cá foi crescendo tudo de maneira que a rainha se saiu do Paço e se meteu na Esperança onde fica e trata de anular o casamento sobre que já corre pleito dizendo que El Rei não é capaz de mulher e ela está donzela [...] dizem que [D. Pedro] há-de casar com a rainha, mas não será tão depressa segundo dizem, como cuidavam, porque diz [D. Afonso VI] que o negócio há-de ir a Roma, e a maior culpa que fazem ao Conde [de Castelo Melhor] e a Henrique [Henriques de Miranda], é dizerem que eles sabiam que El Rei não era capaz de casar" 52 .

Corria a segunda metade de 1666 e, a darmos crédito a algumas notícias acerca do relacionamento entre os monarcas, as informações do marquês de Saint-Romain, somos levados a crer que, imediatamente após o casamento, se tinha verificado um mútuo apreço por parte dos cônjuges. Houve mesmo a divulgação de uma falsa notícia de gravidez, em $1667^{53}$. Porém, sabendo-se que, em 1668, a rainha já se havia separado do marido e contraído novo casamento, seriamos levados a crer que, rapidamente, o casal teria passado a um afastamento e a uma ruptura definitiva. Princesas e infantas eram peças que se jogavam para celebrar uma paz ou selar uma aliança logo, manter um casamento ou anulá-lo não era uma questão meramente do foro familiar ou amoroso era, isso sim, o resultado de uma luta de facções, de partidos dentro de uma corte com o apoio ou o repúdio internacionais.

52 GUIRAUD, M., 1992, pp. 176-177.

$53 \mathrm{O}$ facto de ter dito estar grávida e mais tarde ter afirmado que o marido era impotente não a preocupou. Não foi caso único. Maria Ana de Neuburg, casada, em 1690, com Carlos II de Espanha, também afirmou estar grávida, apesar da fama de impotência do marido. Cf. RÍOS MAZCARELLE, M., 1999. 
Como anteriormente se verificou, ainda D. Afonso VI não havia sido deposto, já D. Maria Francisca Isabel pedira a anulação do casamento, a 22 de Novembro de 1667. Fê-lo em carta ao cabido de Lisboa, explicando a situação e alegando "não haver tido efeito o matrimónio em que nos concertámos" 54 . Recebeu uma resposta não compromedora, pois o cabido limitou-se a lamentar o sucedido e a expressar desejos no sentido de se alcançar a melhor solução ${ }^{55}$. No libelo que entregou, a rainha alegava que o casamento nunca fora consumado em resultado de o monarca ser impotente, o que era público e notório devido a uma doença contraída na infância. Mais acrescentou que, da sua parte, não havia qualquer impedimento "antes a necessaria disposição entre os casados". Já depois do seu afastamento do poder, D. Afonso VI assinou, eventualmente forçado, a 2 de Dezembro de 1667, um documento declarando que nunca consumara o matrimónio ${ }^{56}$. A 26 do mesmo mês, o cabido da sé de Lisboa nomeou os juízes da causa 57 .

Entretanto, o processo ia decorrendo. Para conseguir apoio, a rainha de Portugal não descurou recorrer a França. A 3 de Dezembro de 1667, escreveu ao bispo de Laon, expondo as razões do processo de anulação ${ }^{58}$. Por outro lado, enviou Luís Verjus que, em Paris, actuou junto de Luís II de Bourbon-Vendôme, cardeal duque de Vêndome, legado a latere do papa, e tio materno de D. Maria Francisca Isabel. Este, estante em França para representar Clemente IX no baptizado do filho do monarca francês, partindo do princípio que a anulação já tinha sido concedida, passou, a 15 de Março de 1668, uma autorização apostólica, uma bula de dispensa do impedimento de pública honestidade existente entre os antigos dois cunhados 59 . Entendeu-se que, como legado pontifício, o cardeal tinha os mesmos poderes que o sumo pontífice e, consequentemente, poderia

\footnotetext{
54 Évora, BPE, Cod. CIII/2-25, fol. 14; BENEVIDES, F. F., tomo 2, 1879, p. 107; PAIXÃO, A., vol. 1, 1938, p. 44.

55 Évora, BPE, Cod. CIII/2-25, fol. 14v.

56 Descritpive List of the State Papers [...], vol. 1, p. 80.

57 DÓRIA, A. A., 1944, p. 236.

58 Descritpive List of the State Papers [...], vol. 1, p. 81.

59 SOUSA, A. C., 1952, pp. 70-71; RIBEIRO, M. S., 1938, p. 36; DÓRIA, A. A., 1944, p. 262.
} 
conceder as dispensas matrimoniais. Porém, D. Maria Francisca Isabel manteve as suas preocupações a respeito da situação.

A 24 de Março desse ano, saiu o acórdão. Segundo o mesmo, no espaço que durara o matrimónio, haviam tentando os nubentes consumá-lo, não o logrando "por causa do impedimento que o dito Senhor padece de impotência perpétua respectiva ad virgines, procedida de enfermidade que o dito Senhor teve sendo menino, na dita idade incurável, e já agora irremediavel por arte humana o que tudo se prova superabundantemente pelos meios aprovados por direito, com os quais o dito impedimento fica nos termos de certeza ao menos moral, nos quais termos se não requer inspecção, nem experiência trienal ou de outro tempo arbitrário. O que tudo visto e o mais dos autos, e disposição de direito, julgam o dito matrimónio por contraído de facto e não de direito, e o declaram nulo para que os ditos Senhores possam fazer de si o que bem lhes aprouver"60. O facto de não se ter procedido a um exame médico da rainha não era caso inédito $^{61}$, de qualquer modo preservou-a de qualquer tipo de devassa à sua intimidade.

Não admira, por isso, que, a 1 de Junho de 1668, D. Maria Francisca Isabel estivesse, segundo Saint-Romain, mais calma. Mas faltava ainda a sanção do papa, esperando-se que o cardeal duque de Vendôme, pessoa muito bem relacionada em Roma, não tivesse dificuldades em a obter ${ }^{62}$. Mesmo assim, a rainha despachou o padre de Ville, para este obter uma aprovação pública do sumo pontífice ${ }^{63}$. Esta foi expedida a 10 de Dezembro de 1668, já D. Maria Francisca Isabel estava novamente casada. Nesse documento, Clemente IX fez saber que se tratava não de uma anulação mas de uma dissolução de um vínculo, pois o matrimónio não havia sido consumado $^{64}$. Finalmente, o acórdão de 24 de Março de 1668 foi publicado em Lisboa, a 18 de Fevereiro de $1669^{65}$.

\footnotetext{
60 Causa de Nulidade de Matrimónio [...], pp. 209-210.

61 DARMON, P., 1991.

62 Paris, AMAE-Q'O, Correspondance Politique. Portugal, n. ${ }^{\circ}$ 7, fol. 160.

63 Paris, AMAE-Q'O, Correspondance Politique. Portugal, n. ${ }^{\circ}$ 7, fol. 142.

${ }^{64}$ As Gavetas da Torre do Tombo [...], vol. 9, pp. 714-717.

65 SOUSA, A. C., 1952, pp. 76-78.
} 
Teria o matrimónio de D. Afonso VI com D. Maria Francisca Isabel sido consumado, como tudo indicava pelas cartas que escrevera para França, pelos depoimentos de Saint-Romain e até pelo facto de ter suspeitado estar grávida? Teria a rainha feito tais afirmações antes da consumação do casamento, mas com esperança que tudo se concertasse, querendo apenas evidenciar estar bem quando não poderia estar pior? Seria de uma ignorância notável em matérias do foro fisiológico e sexual? Seria ou não virgem quando se casou com D. Afonso VI? Eis um conjunto de perguntas para as quais só D. Maria Francisca Isabel teria resposta. O facto de ter dito pensar estar grávida e, pouco depois, ter afirmado que o seu casamento não havia sido consumado implica, necessariamente, que, em algum momento, faltou à verdade. Porém, nunca foi confrontada com o facto de ter feito afirmações contraditórias.

Se bem que a rainha tenha proposto às Cortes, através do duque de Cadaval, o seu regresso a França e a restituição do dote, a magna assembleia optou por defender o que menos problemas trazia ao reino: a permanência de D. Maria Francisca Isabel, casada com o regente e, consequentemente, a não restituição do dote ${ }^{66}$, numa época em que o erário público estava bastante esgotado. Por outro lado, evitava-se um problema com a França, que poderia mesmo mover guerra a Portugal. Era o que menos se desejava, tanto mais que o reino acabava de assinar a paz com Castela, a 13 de Fevereiro de 1668.

Em Portugal, este segundo casamento de D. Maria Francisca Isabel contou com opositores e, entre os que não se opunham, com pouco entusiasmo. A excepção, naturalmente, era constituída pelo partido francês. Porém, a questão que se colocou não era amorosa mas política ${ }^{67}$, quer no que se refere às questões internas, como a falta de meios para restituir o dote, quer às questões internacionais, como a criação de um problema grave com França.

A rainha, que passou a princesa, embora quase todos a continuassem a tratar da mesma maneira ${ }^{68}$, enquanto principal interessada, apressou o

\footnotetext{
66 Lisboa, BAC, Manuscritos Azuis, n. 121 (15), fols 130-130v; Paris, AMAE-Q'O, Correspondance Politique. Portugal, n. ${ }^{\circ}$ 7, fol. 104.

67 PÉREZ SAMPER, M. A., 2005, p. 409; SABUGOSA, C., 2006, p. 236.

68 Paris, AMAE-Q'O, Correspondance Politique. Portugal, n. ${ }^{\circ}$ 7, fol. 179, 311.
} 
mais que lhe foi possível o casamento. De tal forma que, tendo chegado de França a dispensa, datada de 16 de Março de $1668^{69}$, expedida antes de pronunciada a dissolução do vínculo matrimonial anterior, logo a 27 do mesmo mês, D. Maria Francisca Isabel concedeu plenos poderes a D. Nuno Álvares Pereira de Melo, duque de Cadaval, e a D. António Luís de Meneses, marquês de Marialva, para estes ajustarem o casamento ${ }^{70}$. Por seu lado, o regente nomeou D. Vasco Luís da Gama, marquês de Niza e D. Rodrigo de Meneses ${ }^{71}$.

No contrato de casamento começou por referir-se a utilidade que se esperava do enlace para a Cristandade e para o sossego e bem comum do reino, para se continuar dando conta que D. Pedro se dava por satisfeito com o dote que a rainha trouxera para o primeiro casamento, o qual fora, entretanto, gasto. O regente comprometeu-se igualmente a conceder a $\mathrm{D}$. Maria Francisca Isabel o mesmo património de que houvera beneficiado sua mãe, D. Luísa de Gusmão, ou seja o que fora instituído pertencer à Casa e Estado das rainhas de Portugal. Para o sustento da Casa, a rainha auferiria 40.000 cruzados. No caso de dissolução do casamento após ter sido consumado ou de viuvez, tendo ou não filhos, a rainha poderia deixar o reino sem perda dos benefícios estipulados no contrato. Porém, no caso de ter descendentes e deixar o reino receberia anulamente 50.000 cruzados, e um terço do dote, no caso de os não ter, ser-lhe-ia restituída a totalidade do dote, as jóias e os outros pertencens, com excepção dos que fossem da Coroa ${ }^{72}$.

O casamento, por procuração, foi realizado no dia 2 de Abril de 1668, quarta-feira de Cinzas. D. Pedro foi então buscar D. Maria Francisca Isabel ao convento da Esperança ${ }^{73}$. A época escolhida, demonstrando a pressa, foi objecto de críticas diversas ${ }^{74}$. Mesmo assim, houve quem visse no facto de o enlace ser celebrado em Abril, um momento auspicioso ${ }^{75}$.

\footnotetext{
69 SANTARÉM, V., 1844, p. 608.

70 SANTARÉM, V., 1844, p. 609.

71 SANTARÉM, V., 1844, p. 609.

72 SOUSA, A. C., 1952, pp. 65-68.

73 DÓRIA, A. A., 1944, p. 274.

74 PAIXÃO, A., vol. 1, 1938, p. 73.

75 ENRIQUEZ DE VILlEGAS, D., 1670, P. 39.
} 
O matrimónio realizado de forma apressada e discreta não suscitou entusiasmo. Em carta a Lord Arlington, Sir Bernard Gascoigne não deixou de referir que "excepto o partido pessoal da rainha, que é muito pequeno, não há ninguém no reino satisfeito com este casamento e, como os cortesãos pensam que será grande motivo de contentamento público haver herdeiros da Coroa, espalham por toda a parte que a rainha está grávida, o que uns acreditam e outros não, de forma que, se a notícia provar que não é verdadeira, não pode deixar de ser em grande prejuízo dela"76. Por outro lado, a 10 de Abril, o cônsul Maynard escreveu a Lord Arlington e informou-o que em Lisboa apareceream panfletos caluniosos contra o novo casal real ${ }^{77}$.

As fontes francesas contrastam com as portuguesas no que à alegria que o casamento do infante D. Pedro com D. Maria Francisca Isabel teria proporcionado em Portugal. Efectivamente, a Gazette noticiou que o mesmo, realizado de forma discreta, tinha contado com "poucas pessoas, mas todas capazes de dar a uma tal acção, o peso e a autoridade de que ela necessitava"78. Por fim, a notícia deu conta da alegria que tal acontecimento tinha proporcionado: "ontem vimos uma alegria pura e inteira nesta Corte, quando a rainha se dirigiu com o príncipe a Alcântara. A tristeza foi universalmente banida para dar lugar à alegria em todo o lado excepto no convento do qual a Princesa saiu, no qual todas as religiosas ficaram chorosas da separação"79, não esquecendo de salientar que D. Maria Francisca Isabel se tinha vestido à portuguesa ${ }^{80}$. Note-se que, vestir-se à moda do país de acolhimento deixando o traje do seu país, é uma das cerimónias iniciais de apropriação da princesa estrangeira ${ }^{81}$. Se a moda francesa dominava o panorama europeu, o momento não era para ousadias mas para atitudes discretas e recatadas e para manobras de alguma diplomacia, com investimento numa imagem.

\footnotetext{
76 MATOS, G. M. 1949, p. 461.

77 Descritpive List of the State Papers [...], vol. 1, p. 87.

78 Gazette, n. ${ }^{\circ}$ 52, Paris, 1 de Maio de 1668.

79 Gazette, n. ${ }^{\circ}$ 52, Paris, 1 de Maio de 1668.

80 CLARETTA, G., 1865, p. 116, ao biografar a rainha, também fez notar que a rainha vestia-se à francesa mas que, quando se casou com D. Pedro optou pelo traje português, o que, naturalmente, muito agradou ao povo.
}

81 PERCEVAL, J. M., 2007, p. 49. 
Pouco tempo após o casamento, D. Maria Francisca Isabel engravidou. A gravidez de uma rainha era assunto de curiosidade e interesse nacionais e internacionais, tanto mais quanto se tratava de dar à luz um herdeiro. Era a maternidade que dava à rainha - enquanto esposa de rei e mãe de um futuro rei - um estatuto e que lhe assegurava a mais importante arma ${ }^{82}$. Ora, a situação política portuguesa, em 1668, era de molde a suscitar sérias preocupações. D. Afonso VI tinha sido afastado da governação, o seu casamento fora anulado, a paz com Castela acabara de ser assinada, o poder estava nas mãos do irmão do monarca, na qualidade de regente, o qual já se casara com a antiga cunhada, e a corte estava dividida. Um herdeiro, de preferência do sexo masculino, não resolvia todos os problemas mas, pelo menos, eliminava uma preocupação significativa: a sucessão do reino.

A criança, do sexo feminino, posteriormente baptizada com o nome de Isabel Luísa Josefa, nasceu a 6 de Janeiro de 1669, no palácio da Corte Real. A nova foi festejada com repiques de sinos, por uma acção de graças e por três dias de luminárias ${ }^{83}$. Este nascimento, num contexto político que carecia de afirmar e reafirmar a sua legitimidade, permitiu que o baptizado da criança constituisse uma oportunidade importante para reforçar a posição portuguesa. Luís XIV foi o padrinho e fez-se representar pelo seu embaixador, o marquês de Saint-Romain ${ }^{84}$.

A 20 de Janeiro de 1674, a princesa, jurada pacificamente nas Cortes reunidas em Lisboa, herdeira presuntiva do trono ${ }^{85}$, foi uma das nove pessoas que, entre os séculos XIV e XVII, foram juradas nas não chegaram a reinar ${ }^{86}$. Contava cinco anos ${ }^{87}$. Qual o papel efectivo de D. Maria Francisca Isabel na educação da sua filha e herdeira do trono de Portugal? Para res-

82 PÉREZ SAMPER, M. A., 2005, p. 407; PERCEVAL, J. M., 2007, p. 42.

83 PAIXÃO, A. vol. 1, 1938, p. 117.

${ }^{84}$ ENRIQUEZ DE VIllegAS, D., 1670, p. 78; PADIlHA, P. N. d'A, 1748, p. 3; SANTARÉM, V., 1844 , p. 625.

85 Lisboa ANTT, Ministério dos Negócios Estrangeiros, cx. 558, doc. 171.

86 BRAGA, I. D., BRAGA, P. D., 2004.

87 PADILHA, D., 1748, pp. 89-105. O juramento foi objecto de notícia na Gazette, n. ${ }^{\circ}$ 31, Paris, 17 de Março de 1674. Ao papa as notícias sobre o mesmo chegaram em carta datada de 22 de Janeiro de 1674. Cf. Cidade do Vaticano, ASV, Lettere della Segreteria di Stato - Portogallo, vol. 26, fols 208-210v. Mais tarde, seguiram cópias dos capítulos das Cortes. Cf. Cidade do Vaticano, ASV, Lettere della Segreteria di Stato - Portogallo, vol. 28, fols não numerados. 
ponder a esta interrogação seria interessante conhecer a própria formação da rainha ${ }^{88}$. Se pouco sabemos acerca do papel materno na educação dos príncipes, no caso em apreço, não podemos deixar de referir que, em 1670, D. Maria Francisca Isabel criticou a educação que D. Luísa de Gusmão dera aos filhos, nomeadamente a D. Afonso VI e a D. Pedro ${ }^{89}$, e fizera saber ao embaixador de França em Portugal, o marquês de Saint-Romain, "que tomaria particular cuidado com a educação da sua filha"90. Por outro lado, o padre d'Orléans considerou que o nascimento da princesa dera à mãe uma nova ocupação, "tornando-a governanta da filha e quase uma ama" 91.

Um relativamente longo documento da lavra da rainha92 deu a conhecer as principais preocupações daquela no que se refere à conduta de D. Isabel Luísa Josefa, enquanto mulher casada. Ora, se tivermos em conta os discursos sobre a educação do príncipe da Época Moderna, decorrentes dos novos ideais de educação preconizados pelas propostas pedagógicas dos humanistas, aliadas às estratégias de legitimação do poder, não poderemos deixar de notar que o texto da rainha é pobre. Efectivamente, se a maioria dos textos então produzidos apresentou como fontes e modelos as Sagradas Escrituras, os autores clássicos e a tradição aristotélico-medieval, evidenciando as qualidades necessárias ao bom governante, com uma sistematização exaustiva das virtudes, cujo primado assentava na ideia de um rei justo e misericordioso, a par de uma feição pedagógica e didáctica93, o mesmo não aconteceu com as indicações fornecidas a D. Isabel Luísa Josefa, pela mãe.

A rainha dividiu o texto, de carácter normativo, dirigido à filha, em quatro partes: deveres para com Deus, para consigo própria, para com a família e, finalmente, para com os vassalos. Assim, D. Isabel Luísa Josefa

\footnotetext{
88 Sobre a formação dos príncipes franceses de então, cf. CORNRTTE, J. 2002, NEVEAU, B., 2002 e MEYER, J., 2004, pp. 23-121.

89 BRAGA, P. D., 2006, pp. 53-54.

90 Paris, AMAE-Q'O, Correspondance Politique. Portugal, n. ${ }^{\circ} 10$, fols 52-55v.

91 D'ORLÉANS, P. J., 1696, p. 74.

92 Este documento foi conhecido no estrangeiro pois os seus biógrafos dos séculos XVII e XIX referem-se-lhe. Cf. D'ORLÉANS, P. J., 1696, pp. 85-114; CLARETTA, G., 1865, p. 210. O mesmo fez o biógrafo da princesa. Cf. PADILHA, P. N. d'A, 1748, pp. 209-236.

93 Sobre este tipo de obras, cf. SOARES, N. C. 1994; BUESCU, A. I., 1996; ABREU, I. S., 2000.
} 
deveria agir de acordo com a sua consciência, evitar pecar e, quando tal ocorresse, procurar imediatamente o confessor, fugir da lisonja, a "peste das Cortes", orar frequentemente ao longo do dia - ao levantar, depois do jantar e antes de dormir - ler obras espirituais ${ }^{94}$ e confessar e comungar a cada 15 dias. Entre os deveres para consigo mesma, contava-se o auto-controlo. Conseguido este, tudo o resto daí decorrente deveria funcionar bem. No que respeita aos deveres para com a família, a princesa deveria respeitar, amar e obedecer aos pais e ao marido, promover a harmonia familiar, nomeadamente entre a família do cônjuge e a sua, aplicar-se no conhecimento do "génio" da pessoa com quem se casou e evitar desagradar-lhe, adaptando-se-1he 95 . Para com os vassalos, D. Isabel Luísa Josefa deveria a todos respeitar e ser prudente, nomeadamente só tomando decisões e deferindo pretensões após se ter bem inteirado dos assuntos 96 . Ou seja, no quadro das virtudes, a herdeira do trono deveria ser uma cristã exemplar, uma esposa cuidadosa e uma governante prudente, o que não destoando da tratadística sobre as virtudes do príncipe, também não se mostrou particularmente desenvolvido, pois apenas ressaltou que a futura rainha deveria ser uma mulher cujo exemplo funcionasse como modelo.

D. Maria Francisca Isabel, mãe pela primeira vez aos 22 anos, estava em perfeitas condições para gerar mais filhos, tanto mais que a gravidez e o parto não tinham sido problemáticos. Logo a 9 de Abril de 1669, poucos meses após o nascimento da primogénita, desvaneceram-se as esperanças de uma nova gravidez da rainha, segundo informações do embaixador de França em Lisboa ${ }^{97}$. A 26 de Setembro do ano seguinte, era o padre António Vieira que informava Duarte Ribeiro de Macedo acerca do eventual estado de graça da mulher de D. Pedro. Segundo o jesuíta, o confessor da rainha

94 Note-se que as obras espirituais estavam sempre presentes nas bibliotecas particulares de leigos e de eclesiásticos de então. Cf. MARQUILHAS, R., 2000, pp. 168-192; FERNANDES, M. L. C., 2000, p. 18. Para Castela, cf. MARTÍNEZ PEREIRA, A., 2003; DADSON, T. J., 2003; REY CASTElAO, M. O., 2003, pp. 135-155; CÁTEDRA, M., 2004, pp. 109-134; PRIETO BERNABÉ, J. M., 2004, pp. 131-160, 175-326.

95 Eventualmente inspirada em Erasmo. Cf. Colóquios, colóquio VI "La Mujer que se queja de su Matrimonio (Mempsigamos)", pp. 130-147.

96 Coimbra, BGUC, Cod. 504, fols 162-165.

97 Paris, AMAE-Q'O, Correspondance Politique. Portugal, n. ${ }^{\circ}$ 9, fol. 117. 
"me dá boas esperanças do que tanto se deseja"98. Porém, ou as esperanças eram infundadas ou a gravidez estava no início.

A 24 de Novembro de 1670, o marquês de Saint-Romain informava a corte de Paris que, tendo observado o comportamento do regente e da sua mulher, se poderia esperar nova gravidez 99 . Efectivamente, a rainha estava grávida. Mas, em Dezembro, uma imprudência fez com que tivesse sofrido um aborto, que a impediu de voltar a procriar. Desconfiava de uma relação amorosa entre o marido e D. Isabel Francisca da Silva e, apesar dos conselhos em contrário, decidiu empreender viagem para ir ao encontro do marido. Para uns, o acidente deu-se à ida para Salvaterra e, para outros, no regresso a Lisboa ${ }^{100}$.

Impossibilitada a rainha de voltar a procriar, todas as atenções se concentraram na única filha do casal. Efectivamente, D. Isabel Luísa Josefa foi, como todas as princesas e infantas, uma peça importante no jogo político internacional. Os vários projectos de casamento envolvendo a herdeira de Portugal nunca lograram êxito, não obstante os empenhos portugueses e franceses. Efectivamente, ao lermos a correspondência diplomática dos enviados e dos embaixadores do rei de França poderemos definir esta matéria como uma das obsessões de Luís XIV. Apesar de ter tido algo como 17 candidatos à sua mão, uns mais consistentes do que outros $^{101}$, a princesa nunca casou. Porém, houve projectos mais próximos de se concretizarem, ao mesmo tempo que, em termos de mercado matrimonial, o valor de D. Isabel Luísa Josefa não foi sempre o mesmo, ao longo da vida. Duas fases são particularmente óbvias: do seu nascimento ao do seu meio-irmão, o príncipe D. João, futuro D. João V, e de então até à sua morte. Nestas duas fases há ainda que contar com o desaparecimento da mãe e com a inversão da tendência francesa a favor do Império então verificada em Portugal, o que desde logo começou a perspectivar novas possibilidades, particularmente desenvolvidas na segunda etapa de vida da princesa.

\footnotetext{
98 VIEIRA, A., 1997, vol. 3, p. 306.

99 Paris, AMAE-Q'O, Correspondance Politique. Portugal, n. ${ }^{\circ}$ 8, fol. 146.

100 Portugal, Lisboa e a Corte [...], p. 113; PAIXÃO, A., vol. 2, p. 104.

101 FARGES, L., 1907.
} 
Apesar do grande número de candidatos, nem todos apresentavam as mesmas prerrogativas. Isto é, sendo o casamento um assunto de extrema importância para Portugal, sobretudo enquanto D. Pedro não teve mais filhos, também é verdade que Castela, o Império e os Estados italianos não deixavam de se manifestar, vislumbrando numa eventual aliança matrimonial não só uma possibilidade de expandirem as suas relações baseadas em laços de casamento, mas também de impedirem o crescente poder da França. Esta, por seu turno, procurava evitar qualquer perda de influência em Portugal. Luís XIV demonstrou sempre particular atenção a esta matéria. Em Janeiro de 1670 , contava a princesa um ano, o rei de França enviou ao seu embaixador, o marquês de Saint-Romain, plenos poderes para propor o casamento de D. Isabel Luísa Josefa com o duque de Anjou, filho segundo do monarca. O diplomata, numa atitude de grande sensatez, considerou o acto prematuro ${ }^{102}$.

Com o reconhecimento pelas Cortes de Lisboa, em 1674, da condição de herdeira presuntiva, as atenções de várias Casas Reais viraram-se para a princesa. A 13 de Março de 1675, em carta a Duarte Ribeiro de Macedo, o padre António Vieira não deixou de notar que às eventuais noivas de Carlos II, rei de Castela - Maria Antónia de Áustria, Maria Luísa de Orleães e Maria Stuart - se poderia juntar a princesa de Portugal "desde o dia do seu nascimento, e muito mais depois que não tem irmão"103. Igualmente sintomático desta realidade foi o comentário de Duarte Ribeiro de Macedo, em Agosto de 1675. O enviado de Portugal em Paris notou que, de Madrid, haviam chegado notícias de que se procurava marido para a princesa em Génova ou Florença, o que lhe motivou as seguintes palavras: "espanta-me que tendo os Castelhanos tanto em que cuidar, cuidem em negócio que está ainda um pouco verde, mas são tão nossos amigos que nenhum outro cuidado os faz esquecer de nós"104.

Em 1675, contava a herdeira seis anos, o padre António Vieira apresentou a primeira candidatura italiana: Fernando (1663-1713), filho primogénito do grão-duque da Toscana, Cosme III de Médicis. O assunto

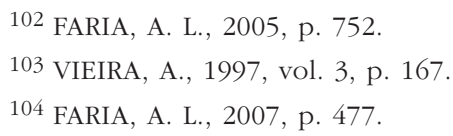


não teve desenvolvimento, pois correram rumores que o rei de França pretendia D. Isabel Luísa Josefa para o delfim, Luís (1661-1711), e que, em Madrid, se falava nela para casar com Carlos II. Cosme III entendeu ser prudente esperar que a situação se clarificasse. Dois anos depois, em 1677, através do cardeal César d'Estrées e de Luís Verjus, ambos ligados à rainha de Portugal, foi proposto o primogénito de Armando de Bourbon e de Ana Maria Matinozzi, sobrinha do cardeal Mazarino, Luís Armando de Bourbon (1661-1685), príncipe de Conti e de La Roche-sur-Yon. Este, apesar de ter contado com importantes apoios, nomeadamente de Luís XIV, de D. Maria Francisca Isabel e de Duarte Ribeiro de Macedo, acabou por ser afastado, por se temer que a epilepsia que grassava na família também o afectasse ${ }^{105}$. No mesmo ano, foi elaborada uma lista com os príncipes solteiros e católicos, para se escolher um candidato cujas qualidade de sangue e idade fossem compatíveis com a herdeira de Portugal ${ }^{106}$. Em 1678, o padre António Vieira orientou-se para o ducado de Parma: Eduardo Farnese (1666-1693), filho de Rainuncio Farnese, descendente de D. Manuel I. Em Abril, chegou a Lisboa o jesuíta Paganino, sob pretexto de desenhar um mapa das casas jesuítas, acabando por propor o enlace ${ }^{107}$. Porém, o projecto também não teve concretização, pois as negociações com Sabóia já estavam em curso.

Outras opções, a que a França sempre se opôs, poderiam ser encontradas no mundo alemão. Nomeadamente, através de algum príncipe de Neuburg ou da Baviera. Aparentemente, era essa a ideia de D. Pedro, que assim tentava cultivar a neutralidade. Pensou-se em Carlos Filipe de Neuburg (1661-1742), filho de Filipe Guilherme, eleitor palatino, que colhia apoios no Inquisidor Geral, D. Veríssimo de Lencastre, e em muitos ministros portugueses. Outra opção seria o príncipe eleitor da Baviera, Maximiliano II (1662-1726), que contava com os mesmos apoiantes do que o anterior e com igual desagrado de Luís XIV.

Mas todos estes candidatos à mão de D. Isabel Luísa Josefa acabaram por ser suplantados por um outro, Vítor Amadeu II, duque de Sabóia,

105 FARIA, A., L., 2005, p. 757; PEREIRA, A. C. D., 2008, p. 78.

106 Lisboa, BA, 51-VIII-26, fols 11-14v, 16-16v.

107 Lisboa, BNP, Ms 10, n. ${ }^{\circ} 1$, fols $11 \mathrm{v}-12 \mathrm{v}$. 
aparentemente contra a própria vontade deste, mas com a bênção ponderada de Luís XIV, e o apoio claro da duquesa viúva de Sabóia, sua mãe, e da da rainha de Portugal, sua tia. Entre 1678 e 1682, Portugal e Sabóia discutiram e festejam a celebração de um casamento que não chegou a acontecer. O projecto, acarinhado pelas mães dos noivos, que assim viam o robustecimento da Casa de Sabóia, da qual ambas eram oriundas, dando origem a um casamento entre primos, tal como fora prática corrente entre Portugal e Castela até ao reinado de D. João III ${ }^{108}$, contou com o apoio pouco entusiasmado de Luís XIV que, contudo, dessa maneira, conseguia vários objectivos: uma maior aproximação entre Portugal e França, iniciada com o casamento de D. Afonso VI, continuada com o do regente e robustecida com o da herdeira, o afastamento de Castela da Coroa portuguesa e, sobretudo, o aumento das possibilidades de anexar o território de Sabóia, uma vez que aquele, sem a presença do duque, ficava bastante vulnerável aos ataques militares franceses 109 .

A 1 de Janeiro de 1678, chegou a Lisboa o abade Spinelli, enviado de Sabóia. Estava encarregado de tratar de vários assuntos do interesse das duas irmãs e, em Maio, acabou por conseguir ajustar a possibilidade da realização do casamento dos filhos de ambas ${ }^{110}$. Em Paris, Duarte Ribeiro de Macedo, com boas relações com o conde João de Gubernatis, enviado de Sabóia em França, estava ao corrente da situação ${ }^{111}$. Segundo Guénegaud, os artigos preliminares relativos ao ajuste do casamento teriam sido acordados até Maio de 1678, quando Spinelli deixou Lisboa, rumo a Madrid. Os Castelhanos continuavam atentos. O abade João Masserati aproveitou a oportunidade para auscultar o duque de Cadaval acerca da possibilidade de um casamento entre a herdeira de D. Pedro e Carlos II. Este projecto contava, inclusivamente, com o apoio de Marcelo Durazzo, núncio em Lisboa. Porém, a oposição era enorme: o visconde de Ponte de Lima, os condes de Vilar Maior, Vimioso, Sarzedas e Ericeira e o duque de Cadaval, não desejavam nova união com Castela112.

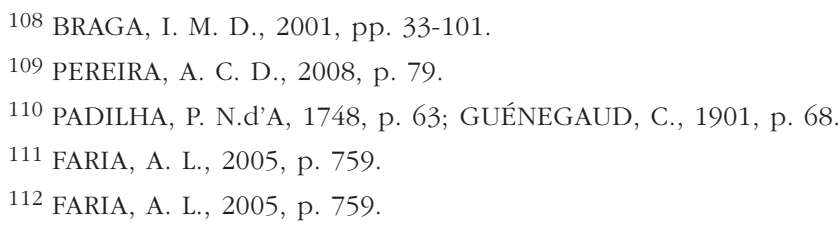


Em Dezembro de 1678, Maria Joana Baptista ordenou ao abade de Verrue, seu embaixador em Paris, que solicitasse o apoio francês para o projecto de casamento. Só em Fevereiro de 1679, Luís XIV deu a sua aprovação. Portugal tinha então em Paris o embaixador Salvador Taborda Portugal e também foi informado desse apoio no mês seguinte. D. Pedro nomeou os seus enviados, a quem deu plenos poderes, o duque de Cadaval e Francisco Correia de Lacerda. O mesmo fez Madame Royale, ao encarregar Carlos d'Este, marquês de Dornero e Spinelli. A 21 de Janeiro de 1679, já D. Luís de Sousa, arcebispo primaz de Braga, escrevia a D. Maria Francisca Isabel, a dar-lhe os parabéns pelo ajuste do casamento em Sabóia113. Em carta datada de 23 de Abril de 1679, o padre António Vieira informava Duarte Ribeiro de Macedo que "corre por coisa sem dúvida termos ajustado o casamento em Sabóia"114. Dias depois, a 1 de Maio, o jesuíta forneceu mais informações ao seu correspondente, não deixando de evidenciar o pouco entusiasmo que nutria pela escolha: "a Princesa está desposada com o duque de Sabóia e já dizem se preparam navios para ir buscar o noivo. Deus nos escolha o melhor, e se sirva de felicitar o pouco aplauso com que este matrimónio é recebido" 115 .

As capitulações matrimoniais foram assinadas a 14 de Maio de 1679116. O casamento só seria celebrado quatro anos depois, isto é, quando a noiva atingisse os 14 anos. A chegada, a 18 de Agosto de 1679, do documento ratificado em Turim deu origem a festejos ${ }^{117}$ e à troca de retratos. O da noiva "era em um anel e o cobria um grande diamante por vidraça"118. Antes, porém, o príncipe regente convocou o Conselho de Estado com vista a deliberar acerca do momento de publicar a notícia do casamento. Até lá, todas as resoluções deveriam ser secretas. Entretanto, por decreto, tornou-se pública a notícia do enlace. Foram informados oficialmente o Conselho da Fazenda, o da Guerra e o Ultramarino, a Casa da Suplicação

\footnotetext{
113 Lisboa, ANTT, Casa Fronteira e Alorna, n. ${ }^{\circ}$ 50, fols 82v-83.

114 VIEIRA, A., 1997, vol. 3, p. 391.

115 VIEIRA, A., 1997, vol. 3, p. 394.

116 Lisboa, BNP, Ms 30, n. 25.

117 Gazette, n. ${ }^{\circ}$ 91, Paris, 7 de Outubro de 1679.

118 PADILHA, P. N. D'A., 1748, p. 118.
} 
e a Mesa da Consciência e Ordens, bem como a nobreza e os embaixadores residentes em Lisboa ${ }^{119}$.

Se, para as famílias reais, casar no estrangeiro era uma norma generalizada, dando origem à constituição de uma vasta parentela à escala europeia, a que Lucien Bély denominou a "sociedade de príncipes"120, também é verdade que se verificaram excepções, as quais favoreciam uma família nacional. Enquanto herdeira da Coroa, a princesa D. Isabel Luísa Josefa estava impedida de contrair matrimónio com um estrangeiro. Tal fundamentava-se numa prerrogativa a que fora dado valor de lei em 1641 e que resultava das falsas Cortes de Lamego. Recordemos que, em 1632, frei António Brandão apresentou um documento apócrifo, pretensamente um traslado das actas das Cortes de Lamego de 1143, encontrado em Alcobaça, no qual estavam estabelecidos, entre outros assuntos, as regras de sucessão do reino. Legitimava-se, assim, a hipótese do duque de Bragança subir ao trono, concretizada em 1640, e obtivera-se um importante documento de propaganda anti-filipina ${ }^{121}$. Ora, por esse falso documento, ao qual se dava crédito, a herança e a sucessão do reino seguiam as ordens da varonia e da primogenitura. Na falta de um varão, a sucessão cabia a uma herdeira desde que esta se casasse com um nobre português. O casamento com um príncipe herdeiro estrangeiro afastá-la-ia e aos seus descendentes da herança do trono. Foi destas determinações que as Cortes de Lisboa, de 1679, dispensam D. Isabel Luísa Josefa, para esta se poder matrimoniar com o duque de Sabóia. Na mesma ocasião, numa conjuntura de grandes dificuldades económicas decorrentes da Guerra da Restauração e suas sequelas, com contestação e motins anti-fiscais ${ }^{122}$, foi pedido um milhão de cruzados para financiar o dote e as despesas do casamento da princesa. Para minimizar os problemas decorrentes deste gasto, optou-se por aumentar o imposto sobre o tabaco e essa notícia chegou ao papado ${ }^{123}$. Outras opções

\footnotetext{
119 Gazette, n. ${ }^{\circ}$ 99, Paris, 4 de Novembro de 1679.

120 BELY, L., 1999.

121 SERRÃO, J. V., 1973, pp. 55-65; MARQUES, A. H. O., 1974, pp. 171-177; CARDIM, P., 1998, pp. 109-111, 115-119.

122 CARDiM, P., 1998, pp. 95-104; OLIVEIRA, A., 2002.

123 Cidade do Vaticano, ASV, Lettere della Segreteria di Stato-Portogallo, vol. 36, fol. 76.
} 
discutidas foram os impostos sobre o sal e o papel selado, para levantar a quantia necessária ${ }^{124}$. O assunto não foi cabalmente resolvido, de tal forma que só a anulação dos esponsais pôs termo ao problema ${ }^{125}$.

A 1 de Janeiro de 1680, chegou o enviado de Sabóia, o conde de Gubernatis $^{126}$, mesmo a tempo de se inteirar dos assuntos discutidos nas Cortes. A estada, destinada a tratar de questões protocolares afectas aos Saboianos que passassem a Portugal, foi curta pois, em Fevereiro, partiu para a corte de Madrid, sem grandes resultados ${ }^{127}$. Em Janeiro do ano seguinte, será a vez de a família real ser visitada pelo marquês de Dornero, Carlos d'Este. A chegada do enviado de Sabóia encurtou o período de lazer da família real em Salvaterra. A 12 de Fevereiro, já D. Maria Francisca Isabel o recebera. A partir de então teve audiência diária ${ }^{128}$. A sua chegada a Portugal foi conhecida e celebrada em Sabóia ${ }^{129}$. Os esponsais foram assinados a 25 de Março 1681. Na ocasião, o regente e a rainha estiveram numa sala decorada com tapeçarias flamengas e persas e posicionaram-se num estrado elevado por três ou quatro degraus. Toda a corte se vestiu de gala ${ }^{130}$. D. Isabel Luísa Josefa não assistiu à cerimónia. Foi representada pelo duque de Cadaval e, posteriormente, cumprimentada no palácio da Corte Real, onde se encontrava ${ }^{131}$. Recebeu de presente um colar ${ }^{132}$. No dia seguinte, a 26 de Março, numa carta ao sobrinho, D. Maria Francisca Isabel expressava sentimentos de amizade, lembrava os antepassados comuns, informava que a festa de noivado tinha decorrido num clima de alegria universal e exortava-o a viajar para Portugal133. Dornero, à partida para Sabóia, recebeu uma rosa de diamantes e um retrato da princesa ${ }^{134}$. Para o conde da Ericeira,

\footnotetext{
${ }^{124}$ Lisboa, ANTT, Ministério dos Negócios Estrangeiros, cx. 558, doc. 174.

125 PEREIRA, A. C. D., 2008, p. 83.

126 Gazette, n. ${ }^{\circ}$ 6, Paris, 20 de Janeiro de 1680.

127 Gazette, n. ${ }^{\circ}$ 18, Paris, 2 de Março de 1680.

128 Gazette, n. ${ }^{\circ}$ 28, Paris, 21 de Março de 1681.

129 Paris, BNF, Fonds Portugais, cod. 37, fol. 117.

130 Cidade do Vaticano, ASV, Lettere della Segreteria di Stato - Portogallo, vol. 37, fols 61-62v.

131 Gazette, n. ${ }^{\circ}$ 39, Paris, 26 de Abril de 1681.

132 FARIA, A. L., 2005, p. 776.

133 Paris, BNF, Clairambault, cod. 589, fols 159-160.

${ }^{134}$ FARIA, A. L., 2005, p. 776.
} 
em carta, de 21 de Abril de 1681, dirigida a Rafael Bluteau, "os esponsais se fizeram com toda a solenidade e grandeza sem juramento algum e restritos à promessa que o duque de Sabóia mandou fazer a Sua Alteza por uma carta que se leu em público em que prometeu de vir para este Reino no ano que vem de [1]682"135.

Em Sabóia, o enviado de Luís XIV, o marquês de Villars, continuou a remeter preciosas informações ao monarca, muito particularmente das atitudes de Vítor Amadeu II. A 22 de Março de 1681, fazia saber que o duque reivindicava mais um ano antes de partir para Portugal e que, em Turim, se procurava obter rendas para fazer face às despesas da ida. Um pedido de 800.000 libras a título de presente de casamento para o duque não fora bem recebido ${ }^{136}$. Por outro lado, em meados de Maio de 1681, já se receava que o contrato de casamento não fosse cumprido. D. Maria Francisca Isabel e Maria Joana Baptista tentavam apressar a partida do duque, temendo manobras por parte da corte de Madrid 137 .

Em meados de 1681, o duque de Cadaval foi nomeado para ir a Turim, na qualidade de embaixador extraordinário, e regressar com o duque de Sabóia138. A 16 de Setembro, em Turim, essa matéria era do conhecimento da corte. De tal modo, que a regente planeou visitar, com o filho, as principais cidades do Piemonte a partir do final de Março do ano seguinte, chegando a Nice em Agosto, de onde embarcaria o duque de Sabóia com o duque de Cadaval ${ }^{139}$. Mas, no ducado, a situação não era estável. Uma relação de Portugal feita pelo marquês de Dornero foi vista como uma sátira do reino, o que enfureceu Maria Joana Baptista, que concluiu ser mais uma manobra para dar motivos ao filho para não querer viajar para Lisboa ${ }^{140}$. Este, entretanto, não perdia nenhuma oportunidade para demonstrar o seu desagrado com o casamento ${ }^{141}$.

\footnotetext{
135 Lisboa, BNP, Ms. 64, n. ${ }^{\circ}$ 8, doc. 13.

136 Paris, BNF, Clairambault, cod. 589, fols 151-156.

137 Paris, BNF, Clairambault, cod. 589, fol. 282.

138 Lisboa, ANTT, Manuscritos da Livraria, n. ${ }^{\circ}$ 1042, fols 289-298; Gazette, n. ${ }^{\circ}$ 75, Paris, 16 de Agosto de 1681 .

139 Paris, BNF, Clairambault, cod. 589, fol. 575.

140 Paris, BNF, Clairambault, cod. 589, fols 424-425.

141 Paris, BNF, Clairambault, cod. 589, fol. 435.
} 
A presença de tropas francesas junto às fronteiras de Sabóia, em Outubro de 1681, forneceu argumentos aos partidários de Vítor Amadeu II e enfraqueceu a posição de Maria Joana Baptista. De facto, apesar de o duque ainda estar no seu território, já os Franceses o ameaçavam. Uma medida de Luís XIV para boicotar um casamento com o qual concordara a contragosto? Perspectivava-se o pior na ausência de Vítor Amadeu II. E, na conjuntura de então, o pior seria a anexação do ducado pelas forças militares de Luís XIV. Assim se compreende que o enviado francês em Turim lamentasse a presença dos Franceses na Citadelle de Cazal, o que tornava a partida do noivo da princesa "muito perigosa [...] enquanto os Franceses estiverem com as tropas nos confins do seu Estado"142. Entretanto, as negociações acerca das facilidades a conceder aos Saboianos no que se refere ao comércio de Portugal e de seus territórios também conheciam algumas dificuldades ${ }^{143}$.

Em Lisboa, a ignorância, pelo menos aparente, do que se passava em Sabóia facilitava a animação face ao casamento. Sabe-se, por exemplo, que, em Janeiro de 1681, já se trabalhava nos preparativos da cerimónia ${ }^{144}$ e que, a 8 de Dezembro, o teatino Manuel Caetano de Sousa, sobrinho do embaixador de Portugal em Roma, defendeu teses dedicadas ao duque de Sabóia, na igreja daquela congregação. Durante o acto, foi pendurado um retrato de Vítor Amadeu II. O duque de Cadaval e a principal nobreza assistiram à efeméride ${ }^{145}$. Em meados de Janeiro de 1682, preparavam-se grandes festas para a recepção do duque, nomeadamente um jogo de canas, composto por oito quadrilhas, de seis cavaleiros cada uma. A chefiar cada quadrilha, o duque de Cadaval, o marquês das Minas, o conde de Sarzedas, o conde de Vale de Reis, o conde de Vila Maior, o conde da Ericeira e o conde da Atalaia ${ }^{146}$. Em Almeirim, D. Pedro também não descurava os preparativos para acolher o genro. Mandara preparar dois apartamentos, uma para D. Isabel Luísa Josefa e outro para Vítor Amadeu II. Na vila, muitas

\footnotetext{
142 Paris, BNF, Clairambault, cod. 589, fol. 647.

143 Paris, BNF, Clairambault, cod. 589, fols 693-694.

144 Gazette, n. ${ }^{\circ}$ 2, Paris, 4 de Janeiro de 1681.

145 Cidade do Vaticano, ASV, Lettere della Segreteria di Stato - Portogallo, vol. 37, fol. 371; Gazette, n. ${ }^{\circ}$ 8, Paris, 17 de Janeiro de 1682.

146 Gazette, n. ${ }^{\circ} 21$, Paris, 28 de Fevereiro de 1682.
} 
casas estavam arrendadas para alojar a nobreza que aí se instalaria, enquanto o duque ali permanecesse ${ }^{147}$.

Ainda em 1682, a 9 de Março, o enviado português na Sabóia, Diogo de Carvalho Sequeira, escrevia a D. Maria Francisca Isabel, comunicando que o futuro genro daquela lhe havia dito que "tinha tanto desejo de se ver nesse Reino como Vossa Majestade tem de o ver nele", mais acrescentando que os cavalos do duque estavam para partir e só a chuva tinha impedido o início da viagem ${ }^{148}$. Poucos dias depois, a 20 de Abril, o mesmo informou a rainha que o duque de Sabóia lhe tinha confidenciado que estava desejoso de chegar a Portugal e de assistir aos espectáculos musicais, pois "melhor lhe haviam de parecer as músicas em Portugal"149. Em Abril, antes da saída do duque de Cadaval que iria a Turim, entendia-se, em Lisboa, que Vítor Amadeu II estava prestes a embarcar, a fazer fé nas notícias publicadas na Gazette ${ }^{150}$.

Finalmente, a 1 de Junho de 1682, partiu o duque de Cadaval numa armada, onde "todos os navios eram magníficos"151, composta por 12 naus e cerca de 6.000 homens ${ }^{152}$. Na perspectiva do núncio, a armada real era tão pomposa quanto poderosa ${ }^{153}$. A frota empreendeu a rota Lisboa Lagos - Nice, onde chegou em meados de Junho. As notícias recebidas acerca da saúde do duque de Sabóia foram desanimadoras. D. Nuno Álvares Pereira de Melo e sua comitiva dirigiram-se então a Turim. A 20 de Julho, o duque de Cadaval informou a corte de Lisboa da doença do duque de Sabóia e, em Lisboa, fizeram-se preces públicas com a exposição do Santíssimo Sacramento, para pedir a Deus a sua cura154. A partida

147 Gazette, n. ${ }^{\circ}$ 25, Paris, 14 de Março de 1682.

148 Paris, BNF, Fonds Portugais, cod. 37, fols 117-118. A 12 de Maio de 1682, ainda os cavalos não tinham chegado, segundo informação de D. frei Manuel Pereira, secretário de Estado, em carta dirigida a Mendo de Fóios Pereira, enviado de Portugal em Madrid. Cf. Lisboa, BA, 54-XIII-17 , n. ${ }^{\circ}$ 86. Os cavalos chegaram a Lisboa e foram posteriormente remetidos a Sabóia quando se desfez o acordo de casamento. Cf. FARIA, A. M., 1929, p. 130; FARIA, A. M., 1948, p. 19.

149 Paris, BNF, Fonds Portugais, cod. 37, fols 119-120.

150 Gazette, n. ${ }^{\circ} 44$, Paris, 16 de Maio de 1682.

151 Gazette, n. ${ }^{\circ}$ 56, Paris, 27 e Junho de 1682.

152 Portugal, Lisboa e a Corte [...], pp. 120-125.

153 Cidade do Vaticano, ASV, Lettere della Segreteria di Stato-Portogallo, vol. 38, fol. 90.

154 Cidade do Vaticano, ASV, Lettere della Segreteria di Stato - Portogallo, vol. 38, fol. 244; Gazette, n. ${ }^{\circ}$ 82, Paris, 5 de Setembro de 1682. 
do noivo de D. Isabel Luísa Josefa, que deveria ocorrer em Agosto, foi sucessivamente adiada. Os médicos portugueses, Fernando Mendes e António Mendes, entenderam que a doença não o impossibilitava de partir. Começou, entretanto, a ser veiculada a ideia de que o filho de Madame Royale não poderia gerar descendência ${ }^{155}$, o que apareceu plasmado num relatório médico secreto da autoria de António Mendes, documento feito a pedido da rainha de Portugal ${ }^{156}$.

Enquanto em Turim, a comitiva portuguesa assistia à doença e às atitudes de Vítor Amadeu II, em Portugal continuou a preparação dos festejos do casamento. Faziam-se arcos triunfais - de diversas profissões e de nações estrangeiras - que seriam colocados em vários pontos de Lisboa; projectava-se uma tourada e já se elevara um mastro com a bandeira real que, de um lado, tinha Nossa Senhora da Conceição, protectora do reino; e, do outro, as armas de Portugal ${ }^{157}$. Entretanto, dando cumprimento ao articulado no contrato de casamento, D. Pedro destinou todas as rendas das terras da Casa de Bragança à filha ${ }^{158}$.

Face aos acontecimentos ocorridos no ducado de Sabóia, D. Pedro e D. Maria Francisca Isabel devem ter ponderado acerca do real interesse do casamento. Ter um genro débil, que viesse contrariado para Portugal e que não tivesse condições para gerar um herdeiro, naturalmente não serviria os interesses nacionais. Decerto, equacionaram até que ponto não se perspectivava a repetição de uma parte das suas vidas. Assim, a 4 de Setembro de 1682, foram enviadas instruções ao duque de Cadaval para este regressar, caso Vítor Amadeu II não embarcasse até ao fim do mês. A 7 de Setembro, o núncio informou a Santa Sé que o duque não viria durante o ano de $1682^{159}$ e, a 26 de Setembro, já os leitores da Gazette sabiam que

155 Teve seis filhos: quatro do casamento com Ana Maria, princesa d'Orleães e dois naturais, cuja mãe foi Joana Baptista d'Albert.

156 PEREIRA, A. C. D., 2008, pp. 83-84.

157 Cidade do Vaticano, ASV, Lettere della Segreteria di Stato - Portogallo, vol. 38, fol. 219; Gazette, n. ${ }^{\circ}$ 68, Paris, 8 de Julho de 1682.

158 Cidade do Vaticano, ASV, Lettere della Segreteria di Stato - Portogallo, vol. 38, fol. 219v; Gazette, n. ${ }^{\circ}$ 75, Paris, 22 de Agosto de 1682.

159 Cidade do Vaticano, ASV, Lettere della Segreteria di Stato - Portogallo, vol. 38, fol. 271. 
o duque de Cadaval ia voltar sem o noivo de D. Isabel Luísa Josefa ${ }^{160}$. A 4 de Outubro, a frota zarpou rumo a Lisboa, onde chegou a 3 de Novembro.

A 10 de Novembro, segundo o embaixador de Luís XIV, a ruptura estava iminente. O duque de Cadaval falava a todos de Vítor Amadeu II como alguém atacado por "todas as enfermidades imagináveis", só sendo possível curar-se por algum milagre. Consequentemente, aconselhava o rompimento do acordo e a celebração de um casamento com a Toscana. Mais cauteloso se mostrava o arcebispo de Braga, D. Luís de Sousa. D. Nuno Álvares Pereira de Melo teria ainda dito que os que desejavam um príncipe francês não estavam a defender os interesses de Portugal pois era necessário manter amizade com França "sem ficar preso"161. Novembro seria um mês decisivo. A 18, segundo o embaixador francês, o duque de Cadaval afirmou que uma recaída do estado de saúde do duque de Sabóia estaria iminente. Porém, as notícias que chegavam não eram consentâneas com os desejos do nobre ${ }^{162}$. A 21, informou que D. Maria Francisca Isabel mostrava total indiferença por tudo o que se referia a Vítor Amadeu II e que o próprio enviado de Sabóia receava pelo duque, caso o casamento se concretizasse e a princesa demorasse muito tempo a engravidar ${ }^{163}$. A 24, d'Oppede informou a corte francesa de que D. Maria Francisca Isabel falava do casamento como algo desfeito e sem "aucun chagrin" e que ouvia o duque de Cadaval cujo comportamento durante toda a estada em Sabóia lhe agradara ${ }^{164}$. Finalmente, a 8 de Dezembro, os sentimentos da rainha acerca do casamento que não se realizaria já eram do domínio público ${ }^{165}$. Em meados do mês, o núncio dava conta de um impasse ${ }^{166}$. Mas, no final desse mesmo mês, o assunto estava esquecido ${ }^{167}$, embora o embaixador de França em Lisboa tenha oferecido a armada real francesa

\footnotetext{
160 Gazette, n. ${ }^{\circ}$ 91, Paris, 26 de Setembro de 1682.

161 Paris, AMAE-Q'O, Correspondance Politique. Portugal, n. ${ }^{\circ} 20$, fols 26v-30v.

162 Paris, AMAE-Q'O, Correspondance Politique. Portugal, n. ${ }^{\circ}$ 20, fol. 35.

163 Paris, AMAE-Q'O, Correspondance Politique. Portugal, n. ${ }^{\circ} 20$, fol. $42 \mathrm{v}$.

164 Paris, AMAE-Q'O, Correspondance Politique. Portugal, n. ${ }^{\circ}$ 20, fols 52, 55v.

165 Paris, AMAE-Q'O, Correspondance Politique. Portugal, n. ${ }^{\circ} 20$, fol. $71 \mathrm{v}$.

166 Cidade do Vaticano, ASV, Lettere della Segreteria di Stato-Portogallo, vol. 38, fol. 353v.

167 Paris, AMAE-Q'O, Correspondance Politique. Portugal, n. ${ }^{\circ}$ 20, fol. 69v.
} 
para transportar o duque, o que foi visto, pelo núncio, como uma mera exibição ${ }^{168}$.

Após a quebra do acordo matrimonial, Maria Joana Baptista escreveu à irmã a lamentar o desfecho e a culpar o duque de Cadaval que falara "publicamente de um modo imperioso na compleição de um príncipe moço do qual ele recebeu todo o género de bons tratamentos e a quem reconheceu por seu príncipe soberano"169. Importa tentar perceber o papel do duque de Cadaval nesta matéria. De facto, quando, através de Salvador Taborda Portugal, enviado de Portugal em França, D. Nuno Álvares Pereira de Melo ficou a saber que Luís XIV pretendia fazer um tratado com Portugal acerca do ducado de Sabóia o que, naturalmente, acabaria com a desejada neutralidade portuguesa; quando verificou não só a oposição dos Saboianos ao casamento mas, e sobretudo, ao presenciar as atitudes de Vítor Amadeu II, terá remetido informações para D. Pedro e D. Maria Francisca Isabel que acabaram, de forma definitiva, com a concretização do projecto. Se a atitude foi deliberada ou uma reacção face às circunstân$\operatorname{cias}^{170}$, não conseguimos saber.

Por seu lado, D. Maria Francisca Isabel explicou-se a Luís XIV. Em carta não datada, informou o primo que as atitudes do sobrinho tinham constituído um contratempo vergonhoso, tornando evidente a fraqueza do temperamento daquele. A situação tinha desencadeado dúvidas terríveis e inultrapassáveis em Portugal, nomeadamente acerca da compleição de Vítor Amadeu II, que deveria ser o suporte da monarquia, já que D. Isabel Luísa Josefa era a única herdeira em linha directa da Coroa portuguesa. Assim, a rainha vira-se obrigada a ter em conta o dever e não a inclinação, optando por seguir o regente na decisão de quebrar o acordo ${ }^{171}$. Cabe perguntar o que pensou a noiva de tudo isto. Porém, as fontes são mudas a respeito dos sentimentos da princesa. Apenas o marquês de Torcy, em 1684, escreveu que a rainha nunca conheceu os sentimentos da filha acerca das

\footnotetext{
168 Cidade do Vaticano, ASV, Lettere della Segreteria di Stato - Portogallo, vol. 38, fol. 370.

169 Coimbra, BGUC, Cod. 504, fol. 208.

170 ANTUNES, A. M. P. O., vol. 1, 1997, pp. 87-89.

171 FRANCISQUE-MICHEL, R. 1882, pp. 238-239.
} 
diferentes possibilidades de casamento, nem mesmo acerca do que esteve em vias de se realizar ${ }^{172}$.

O casamento de D. Isabel Luísa Josefa parece ter sido a questão política que maior interesse suscitou à rainha ao longo da sua estada em Portugal. Não foi a única173. Antes, nos anos de 1672 a 1674, as preocupações da consorte do regente passaram pela tentativa de conseguir a coroação de D. Pedro, assunto que se relacionava directamente com o futuro da filha do casal. As posições de Castela e de Inglaterra eram contrárias, importava, contudo, conseguir a anuência da Santa Sé. A correspondência sigilosa que trocou com Gaspar de Abreu de Freitas, embaixador português junto do papado, é significativa a esse respeito ${ }^{174}$. O mesmo se pode afirmar em relação às notícias que os núncios fizeram seguir para Roma. Na realidade, D. Maria Francisca Isabel falava e servia-se do seu confessor, o padre de Villes, para convencer os representantes da Santa Sé - primeiro Monsenhor Francisco Ravizza (1670-1672), depois Monsenhor Marcelo Durazzo (1673-1685) - da necessidade de o papa ter em consideração este problema, apesar de D. Pedro não estar convencido a assumir o título de rei. Chega a referir-se o mal entendido caso de D. Sancho II, e a sua alegada governação tirânica, que tinha levado o papa a afastá-lo do poder para o reino ter paz e tranquilidade. As objecções inglesas também chegaram a estar previstas tais como as respostas que deveriam ser dadas. Nomeadamente, no que se refere ao facto de a princesa ter nascido antes de D. Pedro ter sido rei em nada diferia da situação de D. João IV enquanto pai de D. Teodósio. Ou seja, D. Catarina não poderia excluir a princesa da sucessão e candidatar-se à Coroa ${ }^{175}$. Monsenhor Durazzo, em vários momentos, ao longo dos anos de 1673 e 1674, notou o empenho do confessor da rainha e a ansiedade da mesma, chegando a escrever: "A Rainha vive ansiosa pela coroação do marido"176.

172 SERRÃO, J. V., 1962, p. 87.

173 BRAGA, I. M. R. M. D., 2011.

174 Paris, BNF, Fonds Portugais n. ${ }^{\circ} 27$, fols 248-256.

175 Cidade do Vaticano, ASV, Lettere della Segreteria di Stato - Portogallo, vol. 26, fols 106, 116, 124, 129-131v, 142, 204-205, 208-210v.

176 Cidade do Vaticano, ASV, Lettere della Segreteria di Stato - Portogallo, vol. 26, fol. 223. 
A não concretização do casamento de D. Isabel Luísa Josefa marcou a fase final da vida da rainha que, entretanto, assistiu ao crescimento da doença que a vitimou. Na actualidade, sabe-se que padecera de sífilis, que herdara do pai ou da mãe, embora uma fonte da época tenha entendido que fora D. Pedro que lhe transmitira essa doença venérea ${ }^{177}$. Na época, a Gazette tal como a correspondência diplomática iam dando conta de pequenos e grandes problemas de saúde de D. Maria Francisca Isabel. No ano da morte da rainha as notícias avolumaram-se. Em Dezembro de 1683, a consorte do monarca (D. Afonso VI tinha entretanto falecido) viu aproximar-se o fim da vida. Pouco antes, mandou lavrar testamento, o qual foi redigido por Sebastião de Matos de Sousa. Como primeiro testamenteiro escolheu o marido e como segundo a filha, a qual instituiu como herdeira universal ${ }^{178}$. Assim, esta recebeu o direito ao dote da mãe, no valor de um milhão de cruzados, que nunca the fora pago, e a casa da rainha, cuja posse foi meramente simbólica, tendo sido administrada pelo duque de Cadaval $^{179}$, tal como o restante património. Concomitantemente, a herdeira passou a ocupar os aposentos que eram da mãe e a ser servida pelos seus oficiais e pelos do pai ${ }^{180}$. O documento de aprovação do testamento foi realizado por D. frei Manuel Pereira, a 21 de Novembro ${ }^{181}$. D. Maria Francisca Isabel escolheu como intercessora celeste a Imaculada Conceição e, no âmbito da "economia da salvação" mandou rezar 20.000 missas com toda a brevidade possível. Diariamente, no mesmo local em que estivesse sepultada, seriam rezadas duas missas e, anualmente, um ofício rezado de nove lições por ocasião do aniversário da sua morte ${ }^{182}$. A leitura do testamento permite ainda verificar a existência de uma verdadeira declaração de amor de D. Maria Francisca Isabel a D. Pedro ${ }^{183}$, uma raridade para a época pois,

\footnotetext{
177 Descritpive List of the State Papers [...], vol. 1, p. 109.

178 BRAGA, P. D., 2007.

179 PEREIRA, A. C. D., 2008, p. 190.

180 Gazette, n. ${ }^{\circ}$ 6, Paris, 12 de Fevereiro de 1684.

181 VALE, T., L. M., 1994, pp. 33 e 67.

182 As Gavetas, vol. 6, pp. 235-243.

183 ANTUNES, A. M. P. O., vol. 1, 1997, p. 55.
} 
então, as manifestações de afecto nos testamentos eram muito contidas ${ }^{184}$ : "Sempre desejei quanto coube na humana fragilidade servir e agradar a el rei meu senhor e marido e porque Sua Majestade é fiel e verdadeira testemunha do muito que sempre o amei não tenho nesta parte que encarecer ao pedir-lhe que pelo recíproco amor que entre nós houve se sirva (por me fazer mercê) de querer ser meu testamenteiro"185.

Falecida D. Maria Francisca Isabel, a 27 de Dezembro de 1683, pelas 15 horas, o seu corpo ficou em exposição, durante o dia 28 , no palácio da Palhavã ${ }^{186}$. Tal como era hábito no século xvII, foi amortalhada com o hábito de uma ordem religiosa ${ }^{187}$, no caso da de São Francisco, querendo com isso significar a entrada numa nova vida alheia aos bens materiais e dedicada à devoção ${ }^{188}$. Por baixo do hábito teria algumas peças de brocado roxo, cujos restos foram encontrados em 1912, quando se procedeu à abertura do túmulo, enquanto se preparava a demolição do convento das francesinhas. O cadáver foi coberto de cal no acto da inumação189.

No seu testamento, D. Maria Francisca Isabel escolheu ser sepultada na capela da Imaculada Conceição do Convento do Crucifixo ou das Francesinhas, junto a São Bento, em Lisboa, edificado por sua ordem ${ }^{190}$. Porém, como à data em que mandou lavrar o testamento, a mesma ainda não estava pronta, decidiu que o seu cadáver deveria ficar em depósito na igreja do noviciado da Companhia de Jesus ${ }^{191}$. Não foi exactamente assim que tudo se concretizou. Tentando evitar gastos futuros, o Conselho de Estado decidiu que o caixão deveria ficar no coro para "ali estar com mais decoro se fica evitando a trasladação e despesas porque se deve fazer então na mesma forma que agora"192. Assim aconteceu.

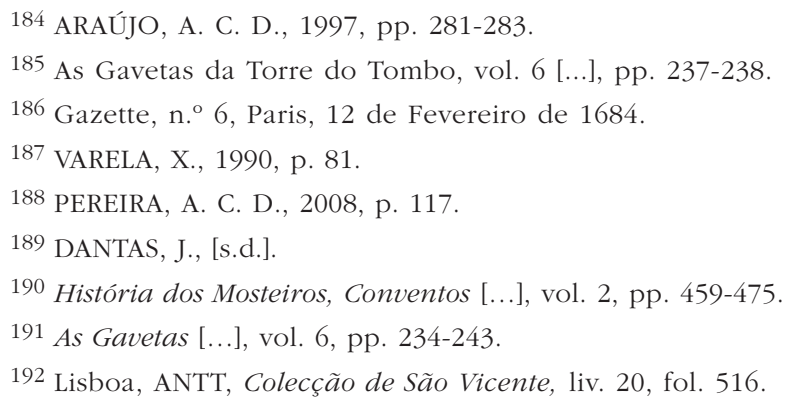


O corpo da rainha foi transportado do palácio da Palhavã, no dia 28 à noite, de forma discreta, segundo o embaixador francês ${ }^{193}$. No testemunho do núncio, tudo se passou com a maior pompa fúnebre ${ }^{194}$. Foi entregue no Convento do Santo Crucifixo das Religiosas Francesas, pelo duque de Cadaval. O caixão, por fora, tinha tela encarnada com ramos de ouro guarnecida com passamanes e, por dentro, foi forrado com telinha branca. Tinha quatro fechaduras, cujas chaves ficaram na posse do mordomo-mor ${ }^{195}$.

Entre os que escreveram sermões e orações fúnebres por ocasião do passamento de D. Maria Francisca Isabel, ou seja, entre os "construtores de imagem” da rainha, na expressão de Euclides Griné196, contam-se o padre D. Rafael Bluteau, frei Constantino de Nantes e o padre António Vieira. Estas peças, ao guardarem a memória dos sucessos políticos, honravam o defunto, publicitavam as suas virtudes e fixavam-nas na memória dos ouvintes e dos leitores ${ }^{197}$. Faziam parte da auto-representação que a corte fazia, assegurando uma audiência mais vasta do que os que tinham participado nas cerimónias ${ }^{198}$.

Em 1912, o Convento do Santo Crucifixo foi demolido. Abriu-se o caixão e estudou-se o esqueleto de D. Maria Francisca Isabel. Foi depois dado novo local de sepultura aos ossos, o antigo refeitório do mosteiro de São Vicente de Fora, onde já se encontravam os restos mortais dos seus dois maridos. Em 1932, a pretexto da morte de D. Manuel II e da aproximação do 25. aniversário do regicídio de 1908, Raul Lino foi encarregado de fazer uma intervenção no local, dando ao espaço o aspecto que ainda se mantem, com os reais despojos colocados em gavetões longitudinais de pedra serrada ${ }^{199}$.

D. Maria Francisca Isabel morreu aos 37 anos, no final de 1683. Viveu 17 anos em Portugal. Por junto, foi rainha consorte durante menos de dois, pois, após o segundo casamento, passou a princesa, embora quase todos

\footnotetext{
193 Paris, AMAE-Q'O, Correspondance Politique. Portugal, n. ${ }^{\circ}$ 21, fol. 114v.

194 Cidade do Vaticano, ASV, Lettere della Segreteria di Stato - Portogallo, vol. 40, fols 7-7v.

195 Lisboa, ANTT, Colecção de São Vicente, liv. 20, fols 524-525; liv. 22, fols 46v-47.

196 GRINÉ, E. S., 1997, p. 114.

197 GRINÉ, E. S., 1997, p. 150.

198 BEPLER, J., 2006, pp. 125-127.

199 DIAS, P. J. M. H. S., 2002.
} 
continuassem a dar-lhe a antiga dignidade. Tal situação só se inverteu com a morte de D. Afonso VI, três meses antes do seu próprio falecimento.

\section{Fontes e estudos}

\section{Fontes manuscritas}

Academia das Ciências de Lisboa (Lisboa)

Manuscritos Azuis, n. ${ }^{\circ} 121$ (15), fols 130-130v.

Archive du Ministère des Affaires Étrangers - Quai d'Orsay (Paris)

Correspondance Politique. Portugal n. ${ }^{\text {s }}$ 5, 7, 8, 9, 10, 20, 21.

Archivio Segreto Vaticano (Cidade do Vaticano)

Lettere della Segreteria di Stato - Portogallo, vols 26, 28, 36-38, 40.

Arquivos Nacionais Torre do Tombo (Lisboa)

Casa Fronteira e Alorna, n. ${ }^{\circ}$ 50, fols 47-60, 82v-83.

Colecção de São Vicente, liv. 20, fols 524-525.

Colecção de São Vicente, liv. 22, fols $47-47 \mathrm{v}$.

Manuscritos da Livraria n. ${ }^{\circ} 1042$.

Ministério dos Negócios Estrangeiros, caixa 558, docs 171, 174.

Biblioteca da Ajuda (Lisboa)

51-VIII-26, fols 11-16v.

54-XIII-17, n. ${ }^{\circ} 56,86$.

Biblioteca Geral da Universidade de Coimbra (Coimbra)

Cod. 504, fols 162-165, 207v-208.

Biblioteca Nacional de Portugal (Lisboa)

Cod. 1505 .

Ms. 10 , n. ${ }^{\circ}$, fols $11 \mathrm{v}-12 \mathrm{v}, 16-20 \mathrm{v}$.

Ms. 30, n. $^{\circ} 25$.

Ms. 64, n. $^{\circ} 8$, docs $5-8,12,13,17$. 


\section{Bibliothèque National de France (Paris)}

Clairambault, n. ${ }^{\circ} 589$.

Fonds Portugais, n. ${ }^{\text {os }} 24,25,27,30,31,32,33,35,37$.

Biblioteca Pública de Évora (Évora)

CIII/2-25.

\section{Fontes impressas}

ABREU, Cristóvão Soares de (1666), Oração de ... em presença das Majestades d'el Rey Affonso VI e da Rainha Dona Maria Francisca Isabel de Saboya, Lisboa, Oficina de José Leite Pereira.

BARBOSA, D. José (1727), Catalogo Chronologico, Historico, Genealogico, e Critico, das Rainhas de Portugal, e seus Filhos, Lisboa Ocidental, Oficina de José António da Silva.

----- (1748), História da Fundação do Real Convento do Santo Cristo das Religiosas Capuchinhas Francesas, Vidas das suas Insignies Fundadoras e de alguns Religiosos Insignies em Virtudes, Lisboa, Oficina de Francisco Luís Ameno.

Causa de Nulidade de Matrimónio entre a Rainha D. Maria Francisca Isabel de Saboya e o Rei D. Afonso VI, reedição aumentada de muitos depoimentos e pareceres inéditos conforme um manuscrito da Torre do Tombo, revista e prefaciada por António Baião, Coimbra, Imprensa da Universidade, 1926.

Certamen Accademico Epitalamico ao Felice Consorcio da Serenissima Rainha D. Maria Francisca Isabel de Saboya com o Invicto Monarcha Lusitano D. Afonso VI na Academia dos Singulares de Lisboa, Lisboa, Oficina de António Craesbeeck de Melo, 1667.

Certamen Epithalemico Publicado na Accademia dos Generosos de Lisboa ao Felicissimo Cazamento da Sempre Augusto e Invicto Monarcha D. Affonso VI no Nome, Rei de Portugal com a Soberana Princeza D. Maria Francisca Isabel, Rainha e Senhora Nossa, Lisboa, Oficina de João da Costa, 1666.

D'ORLÉANS, Pierre Joseph (1696), La Vita de Marie de Savoye Reine de Portugal et de l'Infante Isabelle sa Fille, Paris, Pierre Balland.

ENRIQUEZ DE VILlEgAS, D. Diego (1670), Pyramide natalicio y Baptismal a la Soberana Augusta e Excelsa Magestad de la Serenissima Reyna D. Maria Francisca Isabel de Saboya Princeza de Portugal, Lisboa, Oficina de António Craesbeeck de Melo.

ERASMO (2001), Colóquios, edição e tradução de Pedro P. Santidrian, Madrid, Espasa Calpe.

FARIA, Ana Maria Leal de (2007), Os Cadernos de Duarte Ribeiro de Macedo. Correspondência Diplomática de Paris 1668-1676, Lisboa, Instituto Diplomático.

Gavetas (As), da Torre do Tombo, vol. 6, Lisboa, Centro de Estudos Históricos e Ultramarinos, 1967.

Gazette, Paris, 1666-1684.

GUÉNEGAUD, Claude de (1901), Mémoires Inédites sur le Mariage de l'Infante Isabelle de Portugal (1675-1681), publicadas e anotadas por A. Coche de la Ferté, Paris, Imprimerie Bussière.

História dos Mosteiros, Conventos e Casas Religiosas de Lisboa no qual se dá Nota da Fundação e Fundadores das Instituições Religiosas, Igrejas, Capelas e Irmandades desta Cidade, 2 tomos, Lisboa, Imprensa Municipal de Lisboa, 1972. 
MATOS, Gastão de Melo de (1949), "Notícias da Corte em 1668”, Biblos, vol. 25, Coimbra, pp. 445-472.

Mémoires de Mademoiselle de Montpensier, fille de Gaston d'Orléans, frere de Louis XIII, roi de France, nova edição, tomo V, Maestricht, J. Edme Dufor \& Ph. Roux, 1776.

Mémoires de Monsieur d'Ablancourt, envoyé de Sa Majesté Très-Chrétienne Louis XIV en Portugal, Paris, Heritiers de la Veuve de Mabré, 1701.

PADILHA, Pedro Norberto d' Aucourt (1748), Memorias da Serenissima Princeza D. Isabel Luiza Jozefa, que foy jurada Princeza destes Reynos de Portugal, Lisboa, Oficina de Francisco da Silva.

PAIVA, Sebastião da Fonseca e (1667), Applausos Festivos e Solemnes Triumphos com que os Heroes Portuguezes Celebrarão o Feliz Casamento de dous Monarchas D. Affonso VI e D. Maria Francisca Isabel de Saboya, Lisboa, Oficina de António Craesbeeck de Melo.

[PAIXÃO, Frei Alexandre da] (1938-1939), Monstruosidades do Tempo e da Fortuna, nova edição, publicada sob a direcção de Damião Peres, 4 vols., Porto, F. Machado.

Poetica Discripcion de los Festivos Applausos com que la Nobleza y Pueblo Lisbonense celebró el Felice Casamiento de los monarcas D. Alfonso VI y la Soberana Princesa D. Maria Francisca Isabel de Saboya Reyes Felicissimos de Portugal, Lisboa, Oficina de António Craesbeeck de Melo, 1667.

Portugal, Lisboa e a Corte nos Reinados de D. Pedro II e D. João V. Memórias Históricas de Tristão da Cunha de Ataíde 1. ${ }^{\circ}$ Conde de Povolide, introdução de António de Vasconcelos de Saldanha e Carmen Radulet, Lisboa, Chaves Ferreira, 1990.

SANTARÉM, Visconde de (1844), Quadro Elementar das Relações Politicas e Diplomaticas de Portugal com as Diversas Potencias do Mundo [...], tomo 4, parte II, Paris, Aillaud.

SERRÃO, Joaquim Veríssimo (1962), "Uma Relação do Reino de Portugal em 1684", Boletim da Biblioteca da Universidade de Coimbra, vol. 25, Coimbra, pp. 65-170.

SOUSA, António Caetano de (1952), Provas da História Genealógica da Casa Real Portuguesa, nova edição, revista por M. Lopes de Almeida e César Pegado, tomo V, parte I, Coimbra, Atlântida.

SOUTHWEL, Robert (1749), Histoire du Détrônement d'Alfonse VI Roi de Portugal, tradução do inglês, Paris, David Fils.

VIEIRA, António (1997), Cartas, coordenadas e anotadas por João Lúcio de Azevedo, 3 vols, reimpressão da edição da Imprensa Nacional, de 1970, Lisboa, Imprensa Nacional Casa da Moeda.

\section{Estudos}

ABREU, Ilda Soares de (2000), Simbolismo e Ideário Político. A Educação Ideal para o Príncipe Seiscentista, Lisboa, Estar.

ANTUNES, Ana Maria Pessoa de Oliveira (1997), D. Nuno Álvares Pereira de Melo, $1{ }^{\circ}$ Duque de Cadaval (1638-1727), 2 vols, Lisboa, Dissertação de Mestrado em História Moderna apresentada à Faculdade de Letras da Universidade de Lisboa.

ARAúJO, Ana Cristina (1997), A Morte em Lisboa. Atitudes e Representações. 1700-1830, Lisboa, Editorial Notícias.

Arte Efémera em Portugal, coordenação de João Castel-Branco Pereira, Lisboa, Fundação Calouste Gulbenkian, 2000

BELY, Lucien (1999), La Société des Princes (XVIe-XVIIIe siècles), Paris, Fayard. 
BENEVIDES, Franciscso da Fonseca (1879), Rainhas de Portugal, vol. 2, Lisboa, Tipografia Castro e Irmão.

BENNASSAR, Bartolomé (2006), Le Lit, le Pouvoir et la Mort. Reines et Princesses d'Europe de la Renaissance aux Lumières, Paria, Editions de Fallois.

BEPLER, Jill (2006), "Posterity and the Body of the Princess in German Court Funeral Books", The Body of the Queen. Gender and Rule in the Courtly World, 1500-2000, coordenação de Regina Schlte, Nova York, Oxford, Berghahn Books, pp. 125-155.

BOUZA ALVAREZ, (2001), Corre Manuscrito. Una Historia Cultural del Siglo de Oro, Madrid, Marcial Pons.

BOUZA AlVAREZ, Fernando (1996), "Amor Parat Regna. Memória Visual dos Afectos na Política Barroca", Festas que se fizeram pelo Casamento do Rei D. Afonso VI, Lisboa, Quetzal Editores, pp. 7-26.

BRAGA, Isabel Drumond, BRAGA, Paulo Drumond (2004), "O Juramento dos Herdeiros do Trono em Cortes (séculos xIv-XVII)", As Cortes e o Parlamento em Portugal. 750 Anos das Cortes de Leiria em 1254, Lisboa, Assembleia da República, pp. 245-259.

BRAGA, Isabel Drumond, BRAGA, Paulo Drumond (2007), "Manobras de França na Corte do Príncipe Regente D. Pedro: a Advertência de 1677", Problematizar a História. Estudos de História Moderna em Homenagem a Maria do Rosário Themudo Barata, coordenação de Isabel Drumond Braga e Ana Leal de Faria, Lisboa, Caleidoscópio, Centro de História da Universidade de Lisboa, pp. 207-228.

BRAGA, Isabel M. R. Mendes Drumond (2001), Um Espaço, duas Monarquias (Interrelações na Península Ibérica no Tempo de Carlos V), Lisboa, Universidade Nova de Lisboa, Centro de Estudos Históricos, Hugin Editores.

BRAGA, Isabel M. R. Mendes Drumond (2011), "D. Maria Francisca Isabel de Sabóia (1646-1683)", D. Maria Francisca Isabel de Sabóia e D. Maria Sofia Isabel de Neuburg: Duas Rainhas em Tempo de Novos Equilíbrios Europeus, Lisboa, Círculo de Leitores.

BRAGA, Paulo Drumond (2006), D. Pedro II. Uma Biografia, Lisboa, Tribuna da História.

BRAGA, Paulo Drumond (2007), "Testamentos da Casa Real de Bragança (1656-1704): Devoção, Caridade e Política", Congresso Internacional de História. Territórios, Culturas e Poderes. Actas, vol. 2 (=NW. Noroeste. Revista de História, vol. 3, Braga, 2007), Braga, Universidade do Minho, Núcleo de Estudos Históricos, pp. 91-110.

BUESCU, Ana Isabel (1996), Imagens do Príncipe. Discurso Normativo e Representação (1525-49), Lisboa, Cosmos.

CARDIM, Pedro (1998), Cortes e Cultura Política no Portugal do Antigo Regime, Lisboa, Edições Cosmos.

CÁTEDRA, Pedro M., ROJO, Anastasia (2004), Bibliotecas y Lecturas de Mujeres. Siglo XVI, Madrid, Instituto de Historia del Libro y de la Lectura.

CAVAlHEIRO, António Rodrigues (1944), "Soror Maria da Cruz, Filha Natural de D. João IV. Documentos da Biblioteca de Paris", Anais da Academia Portuguesa da História, vol. 8, Lisboa, pp. 7-76.

ClARETTA, Gaudenzio (1865), Vita di Maria Francesca Elisabetta di Savoia-Nemours Regina di Portogallo com Note e Documenti Inediti, Turim, Tipografia Eredi Botta.

CORNETTE, Joël (2002), "Le Savoir des Enfants du Roi sous la Monarchie Absolu", Le Savoir du Prince du Moyen Age aux Lumières, direcção de Ran Halévi, Paris, Fayard, pp. 111-145.

CORVISIER, André (2002), Les Régences en Europe. Essai pour les Délégations de Pouvoirs Souverains, Paris, Presses Universitaires de France.

COSTA, Fernando Dores (2004), A Guerra da Restauração 1641-1668, Lisboa, Livros Horizonte, 
COX, Harvey (1969), La Fête des Fous. Essai Théologique sur les Notions de Fête et de Fantaisie, Paris, Editions du Seuil.

CUNHA, Mafalda Soares da (2000), A Casa de Bragança (1560-1640). Práticas Senhoriais e Redes Clientelares, Lisboa, Estampa.

CURTO, Diogo Ramada (2007), "Grupos de Rapazes, Violência e Modelos Educativos", Cultura Escrita (séculos XV a XVIII), Lisboa, Instituto de Ciências Sociais, pp. 189-197.

DADSON, Trevor J. (2003), "Las Bibliotecas Particulares en el Siglo de Oro", Historia de la Edición y de la Lectura en España 1472-1914, Madrid, Fundación Germán Sánchez Ruipérez, pp. 123-132.

DANTAS, Júlio [s.d.], "A Caveira de uma Rainha Galante", Arte de Amar, Lisboa, Portugal-Brasil Limitada Sociedade Editora, pp. 155-160.

DARMON, Pierre (1991), "Les Procès pour Impuissance Sexuelle au XVII siècle", Amour et Sexualité en Occident, Paris, Seuil, pp. 229-233.

Descritpive List of the State Papers Portugal 1661-1780 in the Public Record Office. Londres, vol. 1, Lisboa, Academia das Ciências de Lisboa, 1979.

DIAS, Paulo Jorge Monteiro Henriques da Silva (2002), O Real Panteão dos Braganças: Arte e Memória, 3 vols, Lisboa, Dissertação de Mestrado em Arte, Património e Restauro apresentada à Faculdade de Letras da Universidade de Lisboa.

DÓRIA, António Álvaro (1944), A Rainha D. Maria Francisca de Sabóia (1646-1683). Ensaio Biográfico, Porto, Civilização.

FARGES, Louis (1907), L'Infante Isabelle de Portugal et ses Dix-sept Prétendants (1669-1690), Paris, Tipografia Plon-Nourrit.

FARIA, Ana Maria Leal de (2005), Duarte Ribeiro de Macedo. Um Diplomata Moderno. 1618-1680, Lisboa, Instituto Diplomático.

FARIA, António Machado de (1948), "Memorias Historicas de Lisboa (1680-1716)", Lisboa e seu Termo. Estudos e Documentos, vol. 2, Lisboa, Associação dos Arqueólogos Portugueses, pp. 9-98.

FERNANDES, Maria de Lurdes Correia (2000), A Biblioteca de Jorge Cardoso (†1669), Autor do Agiológio Lusitano. Cultura, Erudição e Sentimento Religioso no Portugal Moderno, Porto, Faculdade de Letras da Universidade do Porto.

FRANCISQUE-MICHEL, R. (1882), Les Portugais en France et les Français au Portugal, Paris, Guillard, Aillaud \& C. ${ }^{\text {ie }}$.

GONZALEZ, Christophe (2005), "Deux Textes sur les Relations France-Portugal en l'an 1641: le Triunfo Lusitano de Henrique Gomes et le Triunfo Francês de Jacinto Cordeiro", La France et le Monde Luso-Brasilien: Échanges et Représentations (XVIe-XVIII siècles), estudos reunidos e apresentados por Saulo Neiva, Clermond-Ferrand, Presses Universitaires Blaise Pascal, pp. 141-157.

GRINÉ, Euclides dos Santos (1997), A Construção da Imagem Pública do Rei e da Família Real em Tempo de Luto (1649-1709), Coimbra, Dissertação de Mestrado em História Moderna apresentada à Faculdade de Letras da Universidade de Coimbra.

GUIRAUD, Michèle (1992), "Document Inédit sur les Evenements de 1667 à la Cour de Portugal", Arquivos do Centro Cultural Português, vol. 31, Lisboa, Paris, pp. 171-181.

GUIRAUD, Michèle (2005), "António de Conti, Favori de D. Afonso VI", Revista de História da Sociedade e da Cultura, vol. 5, Coimbra, pp. 101-131.

LEFERME-FALGUIÈRES, Frédérique (2007), Les Courtisans. Une Société de Spectacle sous l'Ancien Régime, Paris, Presses Universitaires de France.

LESNE-JAFFRO, Emmanuèle (2005), "Points de Vue de la Cour de France sur le Portugal (1640-1715)", La France et le Monde Luso-Brasilien: Échanges et Représentations (XVI ${ }^{e}$-XVIII 
siècles), estudos reunidos e apresentados por Saulo Neiva, Clermond-Ferrand, Presses Universitaires Blaise Pascal, pp. 273-291.

LOURENÇO, Maria Paula Marçal (1995), "O Domínio Senhorial da Casa das Rainhas (1642-1781): Património, Estado e Poder”, Amar, Sentir e Viver a História. Estudos de Homenagem a Joaquim Veríssimo Serrão, vol. 2, Lisboa, Colibri, pp. 985-1004.

MARQUES, A. H. de Oliveira (1974), Antologia da Historiografia Portuguesa, vol. 1 (Das Origens a Herculano), Lisboa, Europa-América.

MARQUILHAS, Rita (2000), A Faculdade das Letras. Leitura e Escrita em Portugal no século XVII, Lisboa, Imprensa Nacional Casa da Moeda.

MARTÍNEZ PEREIRA, Ana (2003), "História de la Formación y Evolución de las Bibliotecas", Historia de la Edición y de la Lectura en España 1472-1914, Madrid, Fundación Germán Sánchez Ruipérez, pp. 114-122.

MARTÍNEZ RUANO, Beatriz (2005), "Poder y Conflicto: dos Expresiones de la Fiesta Barroca. Granada, siglo xvII", Religión y Poder en la Edad Moderna, direcção de António Luis Cortés Peña, José Luis Beltrán e Eliseo Serrano Martínez, Granada, Universidade de Granada, pp. 315-327.

MARTINS, Fernando (2004), "Historiografia, Biografia e Ética", Análise Social, vol. 39, n. ${ }^{\circ} 171$, Lisboa, pp. 391-408.

MARTín, José-Luis (2001), "El Proceso de Institucionalización del Modelo Matrimonial Cristiano", La Familia en la Edad Media, direcção de José Luís Martín Rodriguez, coordenação de José Ignacio de la Iglesia Duarte, Logroño, Instituto de Estudios Riojanos, pp. 151-178.

MARTINS, Jorge (2002), O Senhor Roubado. A Inquisição e a Questão Judaica, Póvoa de Santo Adrião, Europress.

MARTINS, José Alberto Ferraz (1987), Casamento e Sociedade no Bispado de Coimbra no Primeiro Quartel do século XVIII. Os Impedimentos de Matrimónio, Coimbra, Dissertação de Mestrado em História Moderna apresentada à Faculdade de Letras da Universidade de Coimbra.

MATOS, Gastão de Melo de (1944), "O Sentido Político da crise se 1667", Anais da Academia Portuguesa da História, vol. 8, Lisboa, pp. 335-440.

MEYER, Jean (2004), L'Education des Princes du XVe au XIXe siècle, Paris, Perrin.

NEVEAU, Bruno (2002), "Futurs Rois très Chrétiens", Le Savoir du Prince du Moyen Age aux Lumières, direcção de Ran Halévi, Paris, Fayard, pp. 197-233.

OliveIRA, António de (2002), Movimentos Sociais e Poder em Portugal no século XVII, Coimbra, Faculdade de Letras da Universidade de Coimbra, Instituto de História Económica e Social.

ORESKO, Robert (2004), "Maria Giovanna Battista of Savoy-Nemours (1644-1724): Daughter, Consort, and Regent of Savoy", Queenship in Europe (1660-1815). The Role of the Consort, coordenação de Clarissa Campbell Orr, Cambridge, Cambridge University Press, pp. 16-55.

PARRALT, David (2002), "Guerra y Relaciones Internacionales", El Siglo XVII. Europa 1598-1715, tradução de Antonio Desmonts, direcção de Joseph Bergin, Barcelona, Crítica, pp. 127-160.

PERCEVAL, José María (2007), "Jaque a la Reina. Las Princesas Francesas en la Corte Española, de la Extranjera a la Enemiga”, Les Cours d'Espagne et de France au XVII siècle, estudos reunidos e apresentados por Chantal Grell e Benoît Pellistrandi, Madrid, Casa de Velázquez, pp. 41-60.

PEREIRA, Ana Cristina Duarte (2008), Princesas e Infantas de Portugal (1640-1736), Lisboa, Colibri.

PÉREZ SAMPER, María de los Angeles (2005), "Las Reinas", Historia de las Mujeres en España y América Latina, vol. 2 (El Mundo Moderno), coordenação de Margarita Ortega, Asunción Lavrin e Pilar Pérez Cantó, Madrid, Cátedra, pp. 399-435. 
PRESTAGE, Edgar (1933), "Castelmelhor e a Rainha D. Maria Francisca", Revista da Universidade de Coimbra, vol. 11, Coimbra, pp. 114-127.

PRIETO, BERNABÉ, José Manuel (2004), Lectura y Lectores. La Cultura del Impreso en el Madrid del Siglo de Oro (1550-1650), vol. 1, Mérida, Junta de Extremadura.

REY CASTELAO, Ofelia (2003), Libros y Lectura en Galicia. Siglos XVI-XIX, Santiago de Compostela, Xunta de Galicia.

RIBEIRO, Benair Alcaraz Fernandes (2007), Um Morgado de Misérias. O Auto de um Poeta Marrano, São Paulo, Associação Editorial Humanitas, Fapesp.

RIBEIRO, Mário de Sampayo (1938), 1667-1668. A Destronação de El-Rei D. Afonso VI e a Anulação do seu Matrimónio, Lisboa, [s.n.].

RÍOS MAZCARELLE, Manuel (1999), Mariana de Neoburgo segunda Esposa de Carlos II, Madrid, Ediciones Merino.

SABUGOSA, Conde de (2006), Damas de Tempos Idos, reedição da segunda edição de 1918, Porto, Fronteira do Caos.

SERRÃO, Joaquim Veríssimo (1973), A Historiografia Portuguesa, vol. 2, Lisboa, Verbo.

SOARES, Nair de Nazaré Castro (1994), O Príncipe Ideal no século xVI e a Obra de D. Jerónimo Osório, Coimbra, Instituto Nacional de Investigação Científica.

VALE, Teresa Leonor M. (1994), D. Frei Manuel Pereira, Bispo e Secretário de Estado. Poder Eclesiástico, Poder Político e Mecenato Artístico na 2. ${ }^{a}$ metade do século XVII, Lisboa, EG.

VARELA, Xavier (1990), La Muerte del Rey. El Cerimonial Funerario de la Monarquia Española (1500-1885), Madrid, Turner.

XAVIER, Ângela Barreto, CARDIM, Pedro (1996), "Imagens das Festas de Casamento de Afonso VI", Festas que se fizeram pelo Casamento do Rei D. Afonso VI, Lisboa, Quetzal Editores, pp. 29-90.

ZANGER, Abby E. (2006), "What the King saw in the Belly of the Beast or how the Lion got in the Queen. Allegories of Royal Procreation in the 1622 Royal Entry into Lyon", The Body of the Queen. Gender and Rule in the Courtly World, 1500-2000, coordenação de Regina Schlte, Nova York, Oxford, Berghahn Books, pp. 103-124. 